\title{
Do Physiological and Spiritual Factors Affect Economic Decisions?
}

\author{
Cem Demiroglu* $\quad$ Oguzhan Ozbas ${ }^{\dagger} \quad$ Rui C. Silva ${ }^{\ddagger} \quad$ Mehmet Fatih Ulu $^{\S}$
}

August 30, 2020

\begin{abstract}
We examine the effects of physiology and spiritual sentiment on economic decisionmaking in the context of Ramadan, an entire lunar month of daily fasting and increased spiritual reflection in the Muslim faith. Using an administrative data set of bank loans originated in Turkey during 2003-2013, we find that small business loans originated during Ramadan are 12 to 17 percent more likely to become delinquent within two years of origination. We find no Ramadan effect for personal loans which are mostly automated, or large business loans where approval decisions are made by credit committees. Loans originated in hot summer Ramadans, when adverse physiological effects of fasting are greatest, and those approved by the busiest bank branches perform worse. Charitable lending does not appear to be a key driver of the Ramadan effect. Despite their worse performance, Ramadan loans have lower credit spreads.
\end{abstract}

JEL classification: G02; G21; Z12.

Keywords: Ramadan; fasting; nutrition; spiritual sentiment; judgment errors; bank lending; religion; religious practice.

We thank three anonymous referees, an anonymous Associate Editor, Philip Bond (the Editor), Claire Cheerier, Igor Cunha, Miguel Ferreira, Christopher James, John Matsusaka, David Scharfstein, Antoinette Schoar, Luigi Zingales, and seminar participants at BI Norwegian Business School, London Business School, Stockholm School of Economics, University of Southern California, and the AFA for helpful discussions.

${ }^{*}$ College of Administrative Sciences and Economics, Koç University, Sarıyer, Istanbul, Turkey 34450, phone: +90-212-338-1620, e-mail: cdemiroglu@ku.edu.tr.

'The Central Bank of the Republic of Turkey, Ümraniye Compound, Saray Mahallesi, Küçüksu Caddesi No:64/B, Ümraniye, Istanbul, Turkey, 34768, phone: +90-312-507-5025, oguzhan.ozbas@tcmb.gov.tr.

ŁLondon Business School, London, UK, phone: +44-0-20-7000-8263, e-mail: rsilva@london.edu.

§College of Administrative Sciences and Economics, Koç University, Sarıyer, Istanbul, Turkey 34450, phone: +90-212-338-0826, e-mail: mulu@ku.edu.tr. 
Many business decisions require the subjective judgment of managers and thus provide fertile ground for understanding the role of psychological and physiological factors in economic decision-making. While a large body of research in behavioral economics has made important progress using a variety of sentiment shocks to shed light on cognitive biases, sentiment shocks induced by spiritual activities remain largely unexplored in the literature. Evidence regarding the role of physiological factors such as nutrition, thirst, and hunger is also scant outside the laboratory.

This paper uses rich micro-level data on bank loans to provide novel evidence on physiological and spiritual effects in credit decisions made by loan officers. Our empirical setting is Turkey's banking industry where we study the performance of loans originated during the lunar month of Ramadan in the Islamic calendar. It is commonplace among Turks, who are predominantly Muslim, to fast without eating and drinking from dawn to sunset for the entire month of Ramadan. As one of the Five Pillars of Islam, fasting is obligatory for believers, ${ }^{1}$ and survey evidence indicates that an overwhelming majority of working adults in Turkey fast during Ramadan. We use local variation in the intensity of fasting offered by the country's geographically diverse regions with variable climates to provide evidence on the physiological effects of thirst and hunger on the quality of credit decisions.

As a religious practice, the experience of Ramadan fasting involves a heightened level of spiritual realization. Fasting is believed to strengthen self-control and develop empathy with those in need. Ramadan is also a time of charitable giving with most Muslims choosing to pay their annual charity tax (zakat, another Pillar of Islam) during the month. These spiritual aspects of Ramadan also allow us to provide evidence on the role of spiritual sentiment in credit decisions. Given the simultaneous nature of spiritual and physiological "treatments" induced by Ramadan, we are careful to recognize the difficulty of isolating pure treatment effects in our interpretations throughout the paper.

The data set for the paper is administrative and covers the universe of bank loans during

\footnotetext{
${ }^{1}$ See Esposito (2018) for a summary of the Five Pillars, acts that are considered obligatory for believers, and for links to related articles at http://www.oxfordislamicstudies.com/article/opr/t125/e1859 (accessed 27Jun-2018).
} 
the period 2003-2013. With extensive information including loan characteristics, borrower and bank branch identifiers, and subsequent default outcomes, we can cleanly estimate the magnitude of decision errors made at the time of loan origination. Although the data set does not feature loan officer identifiers (not even anonymized identity flags) or other types of loan officer information, we can test for the treatment intensity of Ramadan fasting with additional data on branch-level local daily temperature. Because the Islamic calendar is lunar, and the month of Ramadan moves earlier in the Gregorian calendar by ten to twelve days every year, we can also control for seasonal effects.

A further advantage of our empirical setting is that we can conduct a number of placebo tests for the possibility of an unspecified general Ramadan effect. These tests have the ability to falsify any spurious link between Ramadan and the quality of loan officer decisions because certain types of loans do not involve much loan officer judgment due to automation. In particular, personal loans, such as auto loans and residential mortgage loans, are highly automated and granted based on credit scoring models. In contrast, commercial lending decisions rely critically on the judgment of loan officers because most small-sized businesses in the country do not have reliable financial statements, and most business borrowers have undocumented assets and sources of income. Also, differently from small business loan applications that are evaluated by individual loan officers at local branches, medium and large business loan applications tend to be evaluated by credit committees at regional offices or headquarters. This variation in the loan evaluation process allows us to test whether and to what extent committees mitigate individual judgment errors (Sah and Stiglitz, 1986). We conduct additional tests to address concerns about our use of an observational data set and non-random allocation of loans as a potential driver of our findings.

Our main finding is that small business loans originated in the month of Ramadan are more likely to default in the next two calendar years than loans originated in other lunar months. With elevated rates of default ranging from 28 to 40 basis points in different specifications, the Ramadan effect is economically significant - the estimates represent about 12 to 17 percent of the mean rate of default on small business loans. The estimates appear to reflect judgment errors in credit decisions and not a change in hard borrower and loan characteristics during Ramadan 
because we continue to find a significant Ramadan effect after controlling for an extensive set of default-relevant borrower and loan characteristics such as internal risk ratings, loan interest rates, and collateral ratios as well as year, month, bank-branch, and borrower fixed effects. ${ }^{2}$ In addition, default rates jump sharply for loans that are originated at the beginning of Ramadan, compared to loans that are originated just before Ramadan, and they drop once Ramadan ends.

Because there are only 11 Ramadans during our sample period, one may be concerned that extreme events during one or two Ramadans drive our findings. We address this concern in two ways. First, we estimate a default model separately for each calendar year and find a positive and statistically significant Ramadan effect in 8 out of 11 years. Second, we estimate the effect of Ramadan separately for each calendar month that is partially or fully spanned by Ramadan during our sample period and find a positive Ramadan effect for four out of the five calendar months. These results alleviate the concern that our findings are driven by a few outlier events that happen to coincide with Ramadan in our sample.

Our cross-sectional tests point to a significant negative effect of Ramadan on the quality of lending decisions. First, we do not find a Ramadan effect for personal loans that do not involve much loan officer judgment due to automation. Second, we find no Ramadan effect for large business loans, suggesting that decision-making by committees can effectively mitigate individual judgment errors. Third, we find that the Ramadan effect and its statistical significance increases with branch busyness, which implies that reducing the workloads of fasting loan officers can lower potential bank losses due to poor loan officer judgment. Fourth, after controlling for loan officer workload, we find that the Ramadan effect is greater for loans originated on more challenging fasting days such as hot and long summer days. Finally, we find that the Ramadan effect does not vary significantly with the presence of a past bank-borrower relationship, borrower financial strength, or bank liquidity, which suggests that "charitable" or "spiritual" motives are not primary drivers of the Ramadan effect.

We acknowledge that despite extensive controls for default-relevant borrower and loan

\footnotetext{
${ }^{2}$ Conditional on default, we find that the incidence defaults within the first six months following loan origination is higher in the Ramadan sample than in the non-Ramadan sample ( 29 percent versus 25 percent), consistent with worsening credit decisions at origination during Ramadan.
} 
characteristics in our empirical specifications, it is possible that the pool of loan applicants during Ramadan is different in a specific time-varying way that we cannot control for with borrower and branch fixed effects. However, it is unlikely that such a time-varying difference can explain the diverse collection of cross-sectional and placebo findings summarized above. In addition, despite the higher default rates, Ramadan loans have lower credit spreads than non-Ramadan loans, a fact that further reinforces the interpretation that the main Ramadan effect reflects loan officer judgment errors. For instance, even if one were to argue that the main Ramadan effect does not reflect an error in risk assessment, then it must reflect an error in pricing given the default evidence.

In describing our various findings as errors in loan officer judgment, our perspective is an economic one and not whether the mistakes are conscious or unconscious - although one could argue that some of our findings more likely reflect unconscious mistakes whereas others more likely reflect conscious mistakes. Regardless of the precise nature of loan officer decision errors during Ramadan, welfare implications remain unclear. For example, it is possible that the net effect on welfare is positive if Ramadan fasting strengthens self-control and improves creditmarket outcomes outside of Ramadan.

A large body of scholarship in management, economics, and finance examines factors that affect managerial decision-making under uncertainty to understand behavior at the individual and organizational levels. Our paper follows the tradition established by McNamara and Bromiley (1997) to focus on the credit decisions of loan officers. The advantage of focusing on credit decisions is that one can observe a standard day-to-day managerial decision, factors that go into the decision (fundamental default-relevant characteristics of the loan), and ex post outcome (default or no default), making it possible to identify judgment errors. For example, McNamara and Bromiley (1997) find that a simple statistical model based on borrower characteristics better predict the performance of loans than do the assessments of loan officers, reflecting inconsistencies in credit decisions and confirming the view that "man as an intuitive statistician" is liable to incur significant judgment errors in processing information (Peterson and Beach, 1967).

More recently, Corte's, Duchin, and Sosyura (2016) provide evidence that loan officer 
judgment errors in residential mortgage lending decisions arise in part from variation in the psychological state of loan officers based on fluctuations in local sunshine. Fisman, Paravisini, and Vig (2017) find that cultural proximity between loan officers and borrowers mitigates information frictions and improves loan outcomes. Nevertheless, as previous authors have also noted, the disadvantage of focusing on credit decisions made by loan officers is that those decisions may not be representative of the general population of managerial decisions.

Our paper is also related to the social psychology literature on decision fatigue, the finding that individuals become less effective at self-control as they perform more self-control tasks (Muraven, Tice, and Baumeister, 1998). Based on lab experiments, an intriguing explanation involves blood glucose as a limited energy resource that is depleted with repeated attempts at self-control (Gailliot, Baumeister, DeWall, Maner, Plant, Tice, Brewer, and Schmeichel, 2007; Gailliot and Baumeister, 2007). Neuro-imaging studies further support the role of blood glucose (Heatherton and Wagner, 2011). In a setting with experienced professionals, Danziger, Levav, and Avnaim-Pesso (2011) find that parole decisions of Israeli judges are markedly different around their daily food breaks with the probability of a favorable parole decision gradually falling in each decision session. While it is tempting to draw parallels to fasting loan officers, we lack data on the sequence of loan decisions made on any given day. Our data set does not include information on denied loan applications either. ${ }^{3}$

Our paper also contributes to the literature on nutrition and economic activity. Foster and Rosenzweig (1994) find that daily calorie intake is positively associated with workers' effort, productivity, and wages, especially where employment contracts are incentive compatible (see also Strauss (1986); Strauss and Thomas (1998)). Foster (1995) provides further evidence that instead of giving workers incentives to increase calorie consumption by offering them sharecropping type of contracts, employers in their sample prefer to serve meals on the job site and thereby reduce the cost of monitoring calorie intake. More generally, Fogel (2004) argues that

\footnotetext{
${ }^{3}$ Some caution is warranted in relating our work to the studies cited above in the social psychology literature. The resource depletion model of self-control has not replicated in preregistered studies (Hagger, Chatzisarantis, Alberts, Anggono, Batailler, Birt ..., and Zwienenberg, 2016). Depletion of blood glucose as an underlying biological mechanism is also questioned (Kurzban, 2010). Rational time management can explain some aspects of the Danziger et al. (2011) study in simulations (Glöckner, 2016).
} 
one of the principal sources of long-term growth in labor productivity over the past two centuries has been the increase in availability of calories per capita or what he terms physiological capital. These findings appear consistent with the evidence in the bio- medical literature that calorie intake is associated with increases in maximum oxygen uptake (Spurr, 1983, 1988), which increases an individual's ability to work and produce. However, an important difficulty in identifying the causal impact of nutrition on economic outcomes is systematic errors in measurement of calorie intake, which might bias estimated effects of nutrition on productivity and wages (Strauss and Thomas, 1998). We think researchers in this literature can exploit the exogenous shock to calorie intake during daytime in Ramadan to reduce measurement error, similar to Schofield (2014) who uses Ramadan-crop-district variation over time along with uneven spatial distribution of Muslims to study the effect of calorie intake on agricultural productivity in India.

Finally, as shown by Campante and Yanagizawa-Drott (2016), longer Ramadan fasting leads to lower output growth in Muslim countries. While slow growth in Ramadan may to a certain extent be explained by reduced work hours in most Muslim countries, it may also arise in part from managerial judgment errors. Our work represents a first step toward recognizing the presence of a decision-making channel using micro-level data. ${ }^{4}$ In that respect, our paper is part of a reinvigorated literature on the economics of religion (Iannaccone, 1998; Iyers, 2016), and contributes to the line of research investigating the role of religion in shaping individual attitudes toward economic exchange (Guiso, Sapienza, and Zingales, 2003, 2006) and the consequences of religion for economic growth and development (Barro and McCleary, 2003; McCleary and Barro, 2006).

Ramadan observance and its effects on a wider set of corporate decisions likely go unnoticed in societies where Muslims are a small minority. However, lack of awareness can be to the detriment of those societies. According to the Pew Research Center, there were 1.6 billion Muslims

\footnotetext{
${ }^{4}$ See Kuran (2018) for a literature review covering recent contributions that connect Islam to many outcomes of interest to economists. One stream of research in particular uses shocks to prenatal development during Ramadan and finds adverse effects on rates of disability (Almond and Mazumder, 2011) and measures of general health (van Ewijk, 2011), academic achievement (Almond, Mazumder, and van Ewijk, 2015), child labor and employment outcomes at adulthood (Majid, 2015).
} 
in the world as of 2010 (about 23 percent of the world population) and roughly 93 percent of surveyed Muslim adults indicated that they fast during Ramadan. ${ }^{5}$ This suggests that increases in managerial judgment errors during Ramadan might produce significant real effects worldwide, directly in countries with large Muslim populations and indirectly in other countries through international trade and investment.

\section{Background}

Ramadan is the ninth month of the Islamic lunar calendar and the month of obligatory fasting (sawm) for Muslims. Fasting in Ramadan is one of the Five Pillars of Islam and requires abstinence from food, drinks, tobacco, and sexual activity from dawn to sunset for 29 or 30 days, depending on the length of the lunar month. Pre-pubertal children, pregnant women, women during menstruation or post-childbirth confinement and lactation, travelers of long distances, and people with physical or mental illnesses are exempt from Ramadan fasting. Islamic fasting is intermittent, in the sense that there are no calorie restrictions from sunset to dawn.

The daily routine of Ramadan involves a pre-dawn breakfast (suhoor), a fast-breaking meal at sunset (iftar), and a supererogatory late-night prayer which is often performed with the congregation (taraweeh). Figure 1 provides an illustration of daily schedule during Ramadan.

Muslims increase "spiritual" activities such as praying, recitation of the Quran, and donations to charities during Ramadan (Afifi, 1997). Moreover, most Muslims pay their annual charity tax (zakat) during Ramadan - zakat is one of the Five Pillars of Islam, just like fasting; it amounts to 2.5 percent of accumulated wealth and can be paid year-round. At the end of Ramadan, Muslims celebrate the three-day Eid al-Fitr or the Festival of Fast-Breaking, an official holiday in all Muslim-majority countries.

According to a survey conducted by the Pew Research Center in 2012, 97 percent of Turks identify themselves as Muslims and 87 percent of them say they fast during Ramadan. ${ }^{6}$ The

\footnotetext{
${ }^{5}$ Pew Research Center's Forum on Religion \& Public Life, The Future of the Global Muslim Population, 2011, and The World's Muslims: Unity and Diversity, 2012.

${ }^{6}$ In the same survey, $67 \%$ of Turkish Muslims said religion is a very important part of their lives, $27 \%$ said they regularly perform all five obligatory daily prayers, and $72 \%$ said they pay the zakat.
} 
Religious Life Survey conducted in 2014 by the Turkish Statistical Institute (TSI) on behalf of the Presidency of Religious Affairs (PRA) finds a similar propensity of Ramadan fasting (82 percent) based on interviews with 37,624 households. ${ }^{7}$ However, Ramadan observance appears to be less common among Turkish professionals. For example, using a representative sample of 12,000 professionals surveyed during 2006-2011, Barem Research estimates that only 67 percent of Muslim professionals in Turkey observe the Ramadan. ${ }^{8}$

Medical studies provide evidence that Ramadan fasting is associated with moderate increases in dehydration, headache, sleep deprivation, physical exhaustion, and stress-related irritability but no serious health problems (see the references in Leiper and Molla (2003)). These adverse physiological effects of fasting appear to have implications for workplace productivity. For example, Afifi (1997) and Karaağaoğlu and Yücecan (2000) find that fasting reduces motivation to work, concentration, alertness, and cognitive abilities. Also, according to a survey by Dinar Standard (Productivity in Ramadan, 2011), about a quarter of Muslim professionals selfreport a significant reduction in their workplace productivity during Ramadan. Finally, Campante and Yanagizawa-Drott (2016) find that long Ramadan fasting has a negative effect on output growth in Muslim countries. ${ }^{9}$ They attribute the decline in output growth to reduced work hours as well as reduced productivity during work hours.

Recognizing the adverse physiological effects of fasting, governments in Muslim-majority countries tend to officially reduce work hours by one to three hours during Ramadan and adjust them to start and end earlier in the day. ${ }^{10}$ Turkey is one of the few Muslim-majority countries where work hours are not officially adjusted during Ramadan.

Fasting would arguably be more challenging at high temperatures (due, for example, to greater dehydration) or in the summer when the time from dawn to sunset is longer (which might exacerbate the physiological effects of abstaining from food and drinks as well as leaving observers fewer hours for sleep). Time-series variation in the temperature and length of Ramadan

\footnotetext{
7 The Presidency of Religious Affairs (PRA), Survey on Religious Life in Turkey, 2014.

${ }^{8}$ Barem Research, What Ramadan Makes Us Think? Fasting, Praying and Beyond, 2011.

9 They also find that fasting during Ramadan improves the subjective well-being of Muslims.

10 Dinar Standard, Productivity in Ramadan, 2011.
} 
days at a given location largely arises from the fact that the Islamic calendar is lunar and the month of Ramadan moves earlier by ten to twelve days in the Gregorian calendar every year, rotating over the seasons in cycles of roughly 33 years. For example, according to the Turkish State Meteorological Service (TSMS), over the period 1929 through 2017, the average daily temperature in Istanbul, the largest city in Turkey, was $6.0^{\circ} \mathrm{C}$ in January and $23.8^{\circ} \mathrm{C}$ in July. Also, the time between dawn and sunset exhibits substantial variation across seasons in Istanbul: it is 11 hours and 3 minutes on December 21st (the shortest day of the year) and 17 hours and 26 minutes on June 21st (the longest day of the year). Similar seasonal variations in local temperature and the length of day are observed in all other cities. As a result, at a given location in Turkey, fasting would presumably be harder during summer Ramadans than in winter Ramadans.

Note that the propensity to observe the Ramadan could fall as the difficulty of fasting rises, and this would be especially true during summers. Indeed, survey evidence from Barem Research suggests that the percentage of professionals in Turkey who regularly fast during Ramadan falls from around 70 percent in autumn Ramadans to roughly 50 percent in summer Ramadans. Moreover, according to survey evidence from DORinsight Research Co., 44 percent of the surveyed professionals who fasted irregularly or did not fast at all during the Ramadan of 2011 said they could not fast regularly due to hot weather.

\section{Data}

The data for this study come from the required filings of banks with the Banking Regulation and Supervision Agency (BRSA). Specifically, we use electronic files of quarterly bank loan reports for the period 2003-2013. These files cover all personal and business loans made by banks operating in Turkey. Each record in these files is made up of a borrower identifier, bank identifier, branch identifier, city of the branch, type and purpose of the loan, origination date (day/month/year), maturity date, principal amount, currency denomination, annual interest rate, regulatory risk-weight of the loan, regulatory risk classification of the borrower, and the earliest date on which the loan is classified as non-performing, if and when that occurs. For privacy purposes, all personal information about borrowers are masked. Using the available information in each quarterly bank loan report, we create loan identifiers and track loan performance over 
time. For loan performance, we use the date in a dedicated data column where banks report the earliest date on which they classify a loan as non-performing following 90+ days delinquency or when future contractual payments become suspect.

Since we are interested in loan information at loan origination, we drop records about a loan after its first appearance in the quarterly reports while retaining default information from later reports. The resulting raw data set includes about 33 million loans. We drop close to five million loans that do not have borrower identifiers. ${ }^{11}$ We further drop non-cash loans, loans tied to the value of a precious metal, and loans with potentially erroneous entries, e.g., records with negative collateral values, stated time-to-maturity above ten years, missing loan maturities, etc. This data-cleaning stage eliminates about three million loans. We also drop about six million loans made by state-owned banks since credit decisions of those banks are possibly affected by motives other than profit maximization. ${ }^{12}$ Our final data set consists of 18,659,765 loans made by conventional and participation banks. Within this data set, most of our analyses are based on $16,101,481$ small business loans that critically rely on loan officer judgment. The remaining 2,558,284 loans, namely large business loans and personal auto and residential mortgage loans, serve as placebos for loan officer judgment as discussed in the introduction. Small business loans constitute on average 41 percent of the aggregate amount of all outstanding bank loans.

We supplement the loan data in several different ways. First, we obtain from the website of the PRA an official record of Ramadan days in the Gregorian calendar because the dates in our loan data set are in the Gregorian convention. Second, to compare the quality of loan decisions made on Ramadan days with varying degrees of physiological stress on fasting loan officers, we obtain historical city-level daily temperatures from the Turkish State Meteorological Service. Third, to examine the role of bank financial conditions in shaping the quality of loan decisions made in Ramadan, we obtain quarterly bank-level capital adequacy and liquidity ratios from the

\footnotetext{
${ }^{11}$ In reporting information to the BRSA, banks are allowed to bundle loans below a certain size cutoff. The cutoff varies over time and across banks but is never greater than 20,000 Turkish Liras. Personal loans (especially credit card loans) are substantially more likely to be bundled than business loans. Bundled loans have missing borrower identifiers and thus are dropped from our sample.

12 As one might expect, the default rates are substantially higher, and interest rates are substantially lower for state-owned banks than for private banks.
} 
BRSA. Fourth, to calculate credit spreads, we obtain historical daily yields of Turkish Treasury securities from the Central Bank of the Republic of Turkey (CBRT). Finally, to control for bank lending standards at the time of loan origination, we obtain data on Chicago Board of Exchange (CBOE) volatility index (VIX). Giovanni et al. (2019) find that 43 percent of the variation in aggregate bank loan supply in Turkey during 2003-2013 can be explained by variations in the VIX index. They also document a strong co-movement between bank lending rates and the VIX index.

Table I provides summary statistics for the sample of small business loans, the focus of our analyses. Appendix A provides detailed definitions of the variables in this table. Small business loans are defined as loans with a principal amount of one million Turkish Liras (TRY) or less (deflated to 2008 prices using the Consumer Price Index), roughly equivalent to $\$ 770,000$ US Dollars (USD) when translated with the average daily exchange rate 1.30 TRY/USD in $2008 .{ }^{13}$ In coming up with this definition for small business loans, we interviewed several bank managers to better understand the loan approval process at local bank branches. Most banks tend to automate the analysis of "hard" information about loan applicants, e.g., financial statements, collateral assets, credit histories, etc., with a resulting quantitative risk rating and suggested interest rate for each applicant. Armed with that information, local loan officers then have discretion to make lending decisions by adding their "soft" information. The total amount that local loan officers are allowed to lend to small businesses differs across banks, across branches of the same bank, and over time. Most local loan officers have a lending limit of one million TRY or less with the final approval of branch managers. We include branch-level fixed effects in our specifications to account for local differences in the loan approval process. However, we are unable to control for differences across individual loan officers because the data set does not feature identifiers or any other information on loan officers.

It is reassuring to see the main Ramadan effect in simple univariate summary statistics. The average default rate on loans originated during Ramadan (2.69 percent) is 38 basis points higher than the average default rate on loans originated outside of Ramadan (2.31 percent). The difference represents an economically significant 16 percent of the average default rate for the

\footnotetext{
${ }_{13}$ Average daily exchange rate for 2008 is from CBRT's Electronic Data Delivery System.
} 
whole sample (2.34 percent). In addition, Ramadan loans have lower average credit spreads than non-Ramadan loans at origination (4.26 percent for Ramadan loans compared to 4.74 percent for non-Ramadan loans). Again, the difference represents an economically significant 10 percent of the average credit spread for the whole sample (4.70 percent).

In contrast to the evidence of worse performance and lower pricing of Ramadan loans, there is no indication of a change in the observable risk of the borrower pool as Ramadan and non-Ramadan loans have comparable average internal risk ratings, regulatory risk weights, collateralization levels, and maturities. Even low-quality tail measures that focus on marginal borrowers (percentage of borrowers with a default in the past three years) and marginal loans (percentage of loans with a regulatory risk weight greater than 100 percent) show no change during Ramadan. The absence of any significant difference in hard risk characteristics suggests that the main Ramadan effect reflects impaired loan officer judgment of soft information during Ramadan. In that sense, it is apt that our study focuses on small business loans, which require loan officers to collect and process soft information. Also, as we discuss later, in an attempt to help address possible unobservable changes in the pool of loan applicants during Ramadan, we estimate loan default regressions with borrower fixed effects and continue to find that Ramadan loans have significantly higher default rates than non-Ramadan loans.

The average branch busyness is 1.54 in the Ramadan subsample and it is 1.68 in the nonRamadan subsample. The difference represents an 8.4 percent reduction in loan officer workload in Ramadan relative to the whole sample (1.67 percent). The evidence suggests that Ramadan not only reduces the quality of credit decisions, but it might also decrease the supply of bank loans as discussed in detail below.

The average local temperature is substantially higher for Ramadan loans $\left(29.78^{\circ} \mathrm{C}\right)$ than it is for non-Ramadan loans $\left(19.78^{\circ} \mathrm{C}\right)$. This is because during our sample period from 2003-2013, Ramadan has moved back from November to July; July and August are the two warmest months in Turkey. For the same reason, Ramadan loans are approved on days that are, on average, one hour longer than those of non-Ramadan loans. Restricting the sample to loans originated on calendar days that featured Ramadan fasting at least once during the sample period results in similar differences in default rates between Ramadan and non-Ramadan loans. When testing 
whether the difficulty of Ramadan fasting has a causal effect on loan officer judgment errors, we include the direct effects of temperature to isolate an interaction effect due to temperature during Ramadan.

\section{Empirical Results}

\section{A. Quality of Small Business Loan Decisions in Ramadan}

As discussed in the introduction, we would expect the effect of Ramadan on the quality of credit decisions to be greatest for small business loans. First, the discretion of an individual loan officer is crucial in most small business loans, where the credit decision is based more on "soft" qualitative information that the loan officer generates and less on "hard" quantifiable information about the borrower. This is, in part, because, in Turkey, small businesses rarely have audited financial statements and they (or their owners) tend to have undocumented assets and sources of income. Second, other types of loans, such as personal loans and large business loans, can be seen as placebos for loan officer judgment because those loans either involve little loan officer judgment due to significant automation or are approved by credit committees that have the potential to mitigate the judgment errors of individual loan officers.

Our approach is to compare the performance of small business loans originated during Ramadan to the performance of small business loans originated outside of Ramadan. As a measure of loan performance, we consider whether the loan becomes non-performing within two years after origination. The choice of two years is common in the recent banking literature, reflecting a trade-off between measurement accuracy and construct validity. Using a default measure that spans the entire life of a loan is perhaps the most economically relevant measure. However, loan defaults long after origination naturally tend to capture both macroeconomic and borrower-specific shocks more so than loan officer judgment at origination, which is our main interest.

Equation (1) shows our baseline specification for loan performance:

$$
\text { Default }_{i, t+\tau}=\alpha+\beta \Gamma[t \in \text { Ramadan }]+\gamma Z_{i, t}+\kappa_{t}+u_{i, t}
$$


The unit of observation is a unique loan $i$ originated at calendar time $t$. Default $t_{i, t+\tau}$ is an indicator variable that equals one if the loan becomes non-performing between the origination date $t$ and a future time $t+\tau$, which we set to two years throughout the paper; $\Gamma$ is an indicator function that equals one if the loan is originated during Ramadan, and $Z_{i, t}$ is a vector of macroeconomic factors and default-relevant fundamental loan characteristics including interest rate, loan size, loan maturity, internal risk rating of the borrower, and regulatory risk weight of the loan at origination. $\beta$ is the main coefficient estimate of interest, and it shows the effect of loan origination in Ramadan on subsequent loan performance.

A strength of the empirical setting from an identification standpoint is that the Islamic calendar is lunar, which moves the start of Ramadan earlier in the Gregorian calendar by ten to twelve days every year. This allows us to rule out seasonal as well as macroeconomic effects in loan origination and default by including $\kappa$, a vector of month and year dummies. In addition, we saturate most of our specifications with bank-branch fixed effects to address the possibility that time-invariant unobserved differences in loan officer skill or borrower characteristics across bank branches may explain our results.

We estimate Equation (1) using a linear probability model since we have information that allows us to include a series of fixed effects for additional identification (nonlinear models such as probit and logit with multiple sets of fixed effects would result in biased and inconsistent point estimates due to the incidental parameters problem). Another advantage of the linear probability model is the straightforward interpretation of coefficient estimates.

Throughout the paper, we cluster regression standard errors by year-month. ${ }^{14}$ There are two main motivations behind this strategy. First, the administrative data set we use in this paper gives us full coverage of small business loans in the cross-section, but only a draw of 11 Ramadans from a larger population of Ramadans. The effect of Ramadan might be different outside our sample period, for example due to different macro conditions, and clustering standard errors in the time dimension accounts for this uncertainty. Second, the default outcomes of loans

\footnotetext{
${ }^{14}$ In Table IA.II in the online appendix, we show that the main results of the paper (reported in Table II) remain statistically significant under different choices of clustering.
} 
originated in a given month tend to be correlated because loans originated in the same month tend to share background characteristics and are exposed to the same economic environment.

Table II reports the results for small business loans in seven columns. In column (1), we find that small business loans approved during the month of Ramadan are more likely to default than similar loans approved in the rest of the year. Relative to the average default probability of 2.34 percentage points in our sample, the difference between Ramadan and non-Ramadan loans (39.7 basis points) represents a roughly 17 percent higher delinquency rate relative to the sample mean. The specification of this estimate controls for seasonal factors with calendar month and year fixed effects and the risk sentiment in credit markets using the VIX index.

While the inclusion of time fixed effects and the VIX index rules out the possibility that macroeconomic cycles drive the effect of Ramadan on loan performance, it could be that Ramadan loans are riskier and the higher probability of default could be compensated with higher interest rates and loan collateralization. Higher interest rates would provide compensation in the absence of default, while higher collateral to loan value would provide higher recovery rates in the event of default.

In column (2), we control for an extensive set of default-relevant loan characteristics that are available in our data set. Specifically, we control for the purpose of the loan, internal risk rating of the borrower, regulatory risk-weight of the loan, interest rate on the loan (adjusted for inflation), the ratio of collateral to principal amount, loan maturity, the natural logarithm of loan size (adjusted for inflation), and foreign currency dummy. With this additional set of controls including loan pricing and collateralization, we still find that Ramadan loans are more likely to default than non-Ramadan loans by 32 basis points. It follows that loan officers do not sufficiently adjust important characteristics of loan contracts to reflect the elevated default risk of Ramadan loans. It is also reassuring that the Ramadan effect is robust to the inclusion of endogenous loan contract terms whose inclusion could be problematic in terms of over- or under-controlling specifications when estimating treatment effects. The apparent robustness is perhaps unsurprising given the predetermined and varying nature of Ramadan in calendar time.

In column (3), we add branch fixed effects to account for any time-invariant differences in the loan approval process or loan officer skill across bank branches. These fixed effects also span 
time-invariant geographic differences including differences in borrower pools. With the inclusion of this set of fixed effects, we are comparing loans originated in the same branch over time and testing whether loans that are originated during Ramadan are more likely to default than loans originated outside of Ramadan. The estimated coefficient (0.357) implies that based on withinbranch variation, Ramadan loans are about 15 percent more likely to default than non-Ramadan loans. This specification addresses the concern that the Ramadan effect is a composition effect by which branches that approve more risky loans may increase their market share during Ramadan.

In columns (4) to (6), we control for additional sets of fixed effects in our specifications to address further potential concerns about composition. In column (4), we include branch-month fixed effects to control for seasonal factors at the branch level, and find that within a bank branch and calendar month, loans that are approved during the treatment period (when a part of the calendar month coincides with Ramadan) have higher default rates than loans approved during the control period (when the remaining part of the calendar month does not coincide with Ramadan). In column (5), we include branch-year fixed effects to control for location-specific business cycle fluctuations at the branch level, and find that within the same bank branch and year, loans that are approved in the part of the year that coincides with Ramadan have higher default rates than loans approved in the rest of the year that does not coincide with Ramadan. In column (6), we include borrower fixed effects to help address concerns about unobservable changes in the pool of loan applicants during Ramadan that are not captured by our extensive set of controls for loan and borrower characteristics, and find that the Ramadan effect remains statistically significant. The estimates in columns (4)-(6) are comparable to those in columns (1)(3).

Finally, not every calendar day during our sample period 2003-2013 features Ramadan fasting. For example, Ramadan did not take place during the month of January between 2003 and 2013. In column (7), we report the same specification as in column (3) but restrict the sample to loans originated on calendar days that featured Ramadan fasting at least once during our sample period. While this reduces the sample size from more than 16 million observations to less than 6 million, the Ramadan coefficient remains highly statistically significant, and the magnitude is only slightly smaller than its counterpart in column (3). 
Using the coefficients from Table II, a back-of-the-envelope estimate for the incremental cost of Ramadan-induced loan officer judgment errors in our sample from 2003-2013 amounts to 293 million TRY in 2008 prices (or \$226 million USD when translated with the average daily exchange rate of $1.30 \mathrm{TRY} / \mathrm{USD}$ in 2008). To arrive at this estimate, we multiply (i) the aggregate size of small business loans originated in Ramadan (100.8 billion TRY in 2008 prices), (ii) the incremental effect of Ramadan-induced loan officer judgment errors on default rates (0.357 percent), and (iii) a loss-given-default rate estimate for secured small business loans in Turkey (81.5 percent in present value according to Doing Business, a series of annual reports from the World Bank).

\section{B. The Effect of Ramadan by Calendar Year and Calendar Month}

Since we have loan origination data covering only 11 Ramadans, there is a danger that extreme shocks that occurred in one or two Ramadans lead to an increase in default rates. We address this concern in two ways. First, we estimate a separate Ramadan model for each sample year. As shown in Table III, we find a positive and statistically significant Ramadan effect in 8 of the 11 sample years. The equal-weighted mean of the yearly Ramadan coefficients is 0.191 with a standard error of 0.086, indicating a significant Ramadan effect in the time-series. ${ }^{15}$ Second, as shown in Table IV, we regress the likelihood of loan default on Ramadan separately for each calendar month that features Ramadan fasting during our sample period (July, August, September, October, and November) and find a statistically significant Ramadan effect in four of the five calendar months. These results show that the Ramadan effect is a pervasive empirical regularity in our sample. ${ }^{16}$

\section{Loan Officer Judgment}

In Turkey, the approval and pricing of personal loans, such as auto loans and residential mortgage loans, are largely automated through credit scoring models, in part to remove costly

\footnotetext{
${ }^{15}$ The average Ramadan coefficient weighted by the number of loans originated each year is 0.210 .

${ }_{16}$ Note that our strategy of clustering standard errors in the time dimension helps account for the uncertainty that the effect of Ramadan varies over time, e.g., under different macro conditions.
} 
errors in loan officer judgment. In particular, for auto loans and mortgage loans, the approval decision is based on the credit score of the loan applicant (available to banks from the Credit Registry Bureau), monthly documented income of the applicant (the ratio of monthly credit payments to monthly income is generally capped by banks at 50 or 60 percent), age of the applicant (maximum 65 or 70 years), age of the collateral asset being funded (maximum ten years for most structures and five to ten years for used cars), and presence of a co-signer (in the case of used cars). Also, loan rates vary with the applicant's choice of loan amount and maturity. Thus, we would expect Ramadan to have little or no effect on the quality of credit decisions involving personal loans. Similarly, we use medium and large business loans as placebos for loan officer judgment because such loans are typically approved by credit committees and not individual loan officers.

Table V presents regression results by type of loan: medium business loans (column (1)), large business loans (column (2)), mortgage loans (column (3)) and auto loans (column (4)). There are some differences in sample size across the columns. The number of large business loans is lower than the number of medium business loans as one would expect. The number of auto loans is lower than the number of mortgage loans due to the reporting procedure that allows banks to bundle loans below a certain size cutoff. As a result, our sample only includes relatively large auto loans.

As opposed to our findings for small business loans, we find no effect of Ramadan on the quality of loan decisions when loan officers have lower discretion, either because the loan decision is more likely made by a credit committee at a regional office or bank headquarters, as in the case of medium and large business loans (corresponding specifications in columns (1) and (2)), or because the loan approval process is largely automated to remove loan officer judgment, as in the case of personal mortgage and auto loans (corresponding specifications in columns (3) and (4)). These placebo findings further strengthen the inference that the Ramadan effect reflects errors in loan officer judgment during Ramadan.

\section{Loan Price and Risk}

Our main finding so far is that small business loans originated during Ramadan are more 
likely to become delinquent over the next two years than small business loans originated outside of Ramadan. In our specifications, we include an extensive set of default-relevant fundamental loan characteristics as control variables to address concerns about an omitted variable bias due to uncontrolled loan risk. Critically, we control for the interest rate and collateral amount of the loan at origination, two important ex-ante measures of loan risk.

The analysis in this subsection takes seriously the possibility that our linear controls for loan risk may be noisy. Our approach to address this possibility is to examine loan risk as reflected in the interest rate and collateralization of the loan at origination, in the same way we examine loan performance using Equation (1).

Table VI reports the results in six columns. In columns (1) and (2), we focus on the credit spread. To minimize noise in the data, we eliminate foreign currency denominated loans as well as loans for which the credit spread over the maturity-matched Turkish Treasury security is nonpositive. The coefficient estimate on Ramadan is negative in both columns, indicating that small business loans originated during Ramadan are priced as less risky, not more. The coefficient estimates on Ramadan (-0.288 in column (1) and -0.281 in column (2)) imply that, on average, Ramadan loans have 6 percent lower credit spreads than non-Ramadan loans at origination. The difference, however, is not statistically significant at conventional levels.

In columns (3) to (6), we examine whether loans originated during Ramadan have lower expected default losses than loans originated outside of Ramadan, by comparing the collateralization levels of the two groups of loans. We use a continuous collateralization measure (i.e., collateral-to-loan ratio) in columns (3) and (4), and a binary measure indicating whether the loan has any collateral (i.e., collateral amount greater than zero) in columns (5) and (6). Overall, we find a statistically significant but economically small difference between the average collateralization levels of Ramadan and non-Ramadan loans. Specifically, the collateral-to-loan ratio is higher for Ramadan loans than it is for non-Ramadan loans, but the difference only amounts to 1.6 percent without controls for borrower and loan characteristics in column (3), and 1.3 percent with the full set of controls in column (4). Similarly, in columns (5) and (6), we find that the fraction of loans with collateral increases during Ramadan, but by less than 1 percent and in a statistically insignificant way. With loss-given-default estimates for secured commercial loans 
in Turkey above 80 percent according to the World Bank, these estimates imply differences in collateralization that are economically far short of the amount required to provide break-even protection against the increased default risk of Ramadan loans.

Our main finding in Table II that Ramadan loans have higher default rates than nonRamadan loans is also robust to the inclusion of nonlinear second- and third-order polynomials for collateralization. In addition, as shown in Table IA.II in the internet appendix, we find that the difference in default rates between Ramadan and non-Ramadan loans is more pronounced for unsecured loans, which by definition provide no collateral to reduce expected default losses, than it is for secured loans.

We view the evidence on small business loans, namely lower credit spreads at the time of origination (indicating lower credit risk) and similar levels of collateralization in Table VI, and higher default rates in Table II, as conclusively pointing to a decline in the quality of loan officer decisions during Ramadan. The rest of our analyses shed light on the nature of that decline. Unless expressly stated otherwise, our analyses are based on the sample of small business loans for which loan officer discretion matters. We economize on expression and refer to small business loans simply as loans.

\section{E. Role of Religion}

There are at least three non-mutually exclusive channels through which Ramadan observance could impact loan officers' credit decisions. First, loan officers may exert less effort during Ramadan, especially when fasting is physiologically more challenging, which in turn reduces bank credit supply. Second, conditional on approving a loan application, loan officers could make judgment errors due to adverse physiological effects of fasting. Third, heightened state of spirituality during Ramadan could lead loan officers to use discretion in loan approval to benefit borrowers by making what one might call "charitable" loans.

\section{E.1. Role of Fasting}

To identify the physiological impact of fasting on credit decisions, we examine whether the Ramadan effect is greater on physiologically more taxing fasting days. In particular, we expect 
a summer Ramadan with higher temperatures to induce more loan officer mistakes than a nonsummer Ramadan by exacerbating the adverse physiological effects of fasting due to abstaining from eating and drinking during a long and hot day. However, any increase in the difficulty of fasting could be offset by reduced propensity to fast and/or lower effort at work, as discussed previously (see also Campante and Yanagizawa-Drott (2016)). To proxy for the difficulty of fasting, we use the average local temperature over a three-day period ending on the day of loan origination to capture the conditions experienced during loan processing. We also use a dummy variable that equals one if the day of loan origination is in the summer (June, July, or August), and zero otherwise.

We start by studying whether fasting intensity affects the amount of effort exerted by loan officers. Table VII provides evidence on this effort channel, examining how loan origination activity at the branch level varies with the difficulty of fasting. The estimation sample consists of roughly 27 million branch-days. The dependent variable is defined as the natural logarithm of one plus the total number of loans originated at a bank branch on a given day. This variable has a mean of 0.32 and a standard deviation of 0.58 . Our regressions include branch and year fixed effects, as well as average characteristics of loans and borrowers.

In column (1), we find a 0.3 percent reduction in the number of daily approved loans (not statistically different from zero). In column (2), consistent with loan officers responding to the increased difficulty of fasting during hot Ramadan days by reducing the quantity of loans that they approve, the interaction term between Ramadan and local temperature is negative and statistically significant. A ten-degree Celsius increase in temperature during Ramadan results in a 1 percent reduction in branch-level daily loan volume. ${ }^{17}$ Similarly, in column (3), when we use the dummy variable Summer, which captures both high temperature and long days, we confirm that fasting difficulty during summer months is associated with a statistically significant 1.4 percent reduction in loan volume.

In principle, the reduction in loan origination volume on hot and summer Ramadan days

\footnotetext{
${ }^{17}$ The number of observations is lower due to missing temperature data for slightly more than $50 \%$ of the branch-days before 2008 , about $40 \%$ of the branch-days in 2009 , and less than $5 \%$ of the branch-days during 2010-2013.
} 
could improve the performance of approved loans, akin to how the caseload of a bankruptcy judge affects the outcome of a case (Iverson, 2018). If loan officers process fewer loan applications during those days, they could dedicate more time to each application and that in turn could help reduce potential judgment errors. We test this "fatigued effort" hypothesis in Table VIII. Specifically, we first divide loans by each branch within a year into four quartiles based on branch busyness, defined as the total number of small business loans originated by the branch on the loan date. Next, we pool loan data from all the branch-years and estimate default models separately for each quartile. ${ }^{18}$ In column (1), we report the impact of Ramadan in the lowest branch busyness quartile. We find that, in this subsample, Ramadan loans have a 19 basis points higher likelihood of default than non-Ramadan loans. With increasing branch busyness across columns (1) through (4), a striking pattern emerges: Both the economic importance and statistical significance of the Ramadan coefficient increase monotonically with branch busyness. For example, the coefficient estimate on Ramadan reaches 0.65 in the highest branch busyness quartile, indicating a 28 percent increase in default rates relative to the mean default rate in the full sample. Overall, the evidence is consistent with the fatigued loan officer hypothesis and suggests that reducing loan officer workload during Ramadan can help alleviate potential bank losses due to poor loan officer judgment.

In Table IX, we examine whether the effect of Ramadan on the likelihood of default varies with the difficulty of fasting. The evidence so far suggests that (i) loan officers tend to process fewer loan applications when fasting intensity increases (Table VII), and (ii) the Ramadan effect increases monotonically with branch busyness (Table VIII). Thus, when testing for a relationship between fasting intensity and loan outcomes, it is important to account for loan officer workload. We do this in two ways. First, we include interactions between branch busyness and fasting difficulty during Ramadan. Second, we focus on the subsample of loans in the top busyness quartile for each branch within a year.

In column (1) of Table IX, we include the interactions of the variables, Local temperature $\left({ }^{\circ} \mathrm{C}\right)$, Ramadan, and Branch Busyness. The coefficient on the interaction term between Ramadan and

\footnotetext{
${ }_{18}$ The number of loans in the first quartile (Q1) exceeds the number of loans in the other three quartiles (Q2 to Q4) because of the large number of branch-days with only one new loan.
} 
local temperature is positive and statistically significant, indicating that, even in branches without a heavy workload in Ramadan, increased fasting intensity due to warmer temperatures results in higher default rates. In addition, we find that the triple interaction term between Ramadan, local temperature, and branch busyness is also positive and statistically significant, implying that the effect of warmer temperatures in Ramadan increases with branch busyness. In busy branches, a one additional degree in the Celsius scale on a Ramadan day leads to a 7-basis point increase in the probability of loan default within two years. The interaction effects are large enough to reduce the direct Ramadan coefficient by about two thirds and make it statistically insignificant.

In column (2), we control for loan officer workload by focusing on the subsample of busy branch days (the busiest quartile of days for each branch each year). Consistent with the evidence in column (1), we find that high temperatures during Ramadan adversely affect the quality of lending decisions of busy loan officers. We confirm these results in columns (3) and (4), where we employ the variable Summer as a proxy for the difficulty of fasting. The estimates in column (4) imply that loans approved in busy bank branches during hot and long summer Ramadan days are 74 basis points more likely to default than loans approved in busy branches during nonsummer Ramadan days.

Overall, the results in this subsection suggest that adverse physiological effects of fasting (as measured by branch busyness and fasting intensity) are a critical source of loan officer judgment errors during Ramadan. To the extent that the intense experience of fasting on a hot Ramadan day primes spiritual feelings, the estimates could further reflect "charitable lending" by loan officers, which we explore next.

\section{E.2. Charitable Lending}

As discussed in Section I, most practicing Muslims make donations to charities and pay their obligatory annual charity tax (zakat) during Ramadan. It is possible that these and other practices during Ramadan temporarily influence loan officers' beliefs and values that determine their credit decisions. ${ }^{19}$ In particular, in Ramadan, loan officers could be more inclined to approve

${ }_{19}$ On the borrower side, Baele, Farooq, and Ongena (2014) use an administrative data set of outstanding 
"charitable" loans to clients with whom they are acquainted and have personal relationships, and when the bank is sufficiently strong financially to tolerate such loans (see Campante and Yanagizawa-Drott (2016) for a similar argument). If charitable loans increase during Ramadan, we expect the Ramadan effect to be concentrated among loans involving past clients and financially strong lenders. Conversely, if charitable loans do not increase during Ramadan, the Ramadan effect would be homogeneous across different types of borrowers and lenders.

We test for the presence of charitable Ramadan lending in Table X. In column (1), the interaction term between Ramadan and the past client indicator is positive but statistically insignificant, suggesting that bank lending during Ramadan does not involve loan officer support to undeserving past clients (Drexler and Schoar, 2014). In column (2), the interaction term between Ramadan and the lending bank's liquidity ratio is also positive but statistically insignificant, which is inconsistent with charitable lending during Ramadan based on lender financial strength (as measured by bank liquidity).

However, we do find some suggestive evidence consistent with the presence of charitable lending during Ramadan when we measure financial strength of the lender using bank capital adequacy ratios. In column (3), the interaction term between Ramadan and the lending bank's capital adequacy ratio is positive and statistically significant. The coefficient estimate implies that a loan extended in Ramadan by a bank with a one percentage point higher capital adequacy ratio has an 11-basis points higher probability of default within two years. To check whether this result is driven by Islamic banks that could operate with high capital adequacy ratios (Beck, DemirgüçKunt, and Merrouche, 2013), we restrict the sample to loans originated by conventional banks in column (4). The interaction term remains positive and statistically significant. ${ }^{20}$ Finally, in column (5), we restrict the sample to secured loans and observe that the interaction between Ramadan and bank capital adequacy ratio becomes insignificant. This suggests that if loan officers of well

business loans in Pakistan in the period 2006-2008 and find that borrowers of Islamic loans are less likely to default, and even less so during Ramadan.

${ }^{20}$ As the results in columns (3) and (4) imply, the interaction term is weaker for participation banks than it is for conventional banks. We note that there is much less time-series variation in the capital adequacy ratios of participation banks, making it harder to identify a charitable lending effect for them as compared to conventional banks. 
capitalized banks engage in charitable lending, they restrict it to borrowers who are unable or unwilling to provide collateral to secure their loans.

We also interviewed a number of bank managers to determine whether banks have an official policy of lending "differently" during Ramadan. The responses that we received were all negative. In addition, we searched through banks' annual reports and did not find any mention of charitable lending alongside usual social responsibility projects in the arts, environment, and education. ${ }^{21}$ One plausible way in which our findings could arise is that financially weaker banks do more to prevent charitable lending because they cannot afford it. We note that the evidence on the charitable lending channel is inevitably indirect because loan officer intent is inherently unobservable. The fact that the Ramadan effect is more pronounced for financially stronger banks is suggestive of charitable lending. In addition, the economic magnitudes implied by the estimates seem too large to be dismissed as entirely spurious. Nevertheless, the possibility remains that there are alternative explanations other than charitable lending.

\section{F. Alternative Mechanisms}

In this subsection, we explore a number of alternative mechanisms as drivers of the Ramadan effect and report the results in Table XI. Some of the mechanisms can be seen as being solely borrower-based, although the process of loan approval requires some worsening in screening by loan officers to allow borrowers to drive the Ramadan effect.

We first examine the possibility that the Ramadan effect may be driven by changes in the workload mix of loan officers during Ramadan. Specifically, if observant loan officers process fewer loans and nonobservant loan officers process more loans during Ramadan, then a Ramadan effect could arise to the extent there are skill differences between the two groups of loan officers. An alternative related hypothesis is that observant and nonobservant loan officers have no skill differences, but nonobservant loan officers do a worse job when they process more loans during

${ }^{21}$ While a full understanding is beyond the scope of this paper, the absence of an official program for charitable Ramadan lending could be due to several reasons: (i) no matter how carefully designed, the program's ex-post losses could be difficult to limit, (ii) there could be too many applications, disrupting normal operations, and (iii) the program could impose severe haggling costs outside of Ramadan. 
Ramadan, perhaps due to work fatigue.

To explore these hypotheses, we test whether there are differences in the Ramadan effect among bank branches based on the number of unique borrowers at the branch level. If changes in workload mix lead to worse decisions during Ramadan, we would expect the Ramadan effect to be stronger where changes in workload mix are more likely to occur, namely larger branches that have more loan officers.

The specification in column (1) includes the natural logarithm of the number of unique borrowers and its interaction with Ramadan. The coefficient estimate on the interaction term is economically small and statistically insignificant, suggesting that the Ramadan effect is unlikely driven by changes in workload mix. Even so, we caution against drawing strong conclusions because we do not observe loan officer-level workload to compute changes in workload mix -it could be that there is no relation between branch size and changes in workload mix during Ramadan.

Another possibility is that the Ramadan effect partly reflects increased social mixing around religious meals and ceremonies during Ramadan. We think this is somewhat unlikely in Turkey because differently from the tradition brought by Muslims from countries in the Middle East and the Indian subcontinent to Western countries, Turks do not have a tradition of breaking the Ramadan fast at mosques or other social gatherings. Late-night Ramadan prayers do not lead to much social mixing in Turkey either. Nevertheless, as a mechanism, increased social mixing is broad enough that it could be a driver of the Ramadan effect in Turkey, perhaps through interactions other than Ramadan dinners or late-night prayers. To explore this hypothesis, we test for differences in the Ramadan effect between bank branches located in large and small cities with the assumption that if social mixing is a driver of the Ramadan effect, the mechanism is more likely to operate, and hence affect loan decisions, in smaller cities.

In column (2), we find that the Ramadan effect is similar across bank branches located in small and large cities. The coefficient on the interaction term between Ramadan and the small city indicator (below median city population) is economically small (-0.107) and statistically insignificant. Since we also find little difference between small and large bank branches (one would expect the likelihood of social interactions with clients to be higher at smaller branches), 
increased social mixing during Ramadan is an unlikely driver of the Ramadan effect. As with the previous test, we caution against drawing strong conclusions because we lack a direct measure of social mixing during Ramadan.

The Ramadan effect could also arise if borrowers are fatigued or distracted by Ramadan observance. For instance, if entrepreneurial effort during the early stages of a new project is critical for its long-run success, then projects that are started during Ramadan conceivably have a heightened risk of failure (it is also necessary that this risk is not fully recognized by loan officers). To test this hypothesis, we construct a first-time loan indicator that equals one if the loan is the first loan of a borrower in the data set. To reduce false positives in identifying first-time loans in the early years of the data set, we set this indicator variable to missing for loans originated in 2003 and 2004. If "entrepreneur fatigue" during Ramadan leads to worse project outcomes, we would expect the Ramadan effect to be larger for first- time loans. In column (3), we find that firsttime loans have higher default rates than non- first-time loans in general (23 basis points). Importantly, first-time loans have similar default rates whether they are originated during Ramadan or not-the coefficient estimate on the interaction term between Ramadan and firsttime loan indicator is statistically insignificant at conventional levels. This is inconsistent with "entrepreneur fatigue" being a driver of the Ramadan effect. ${ }^{22}$

To further shed light on possible mechanisms, we consider loan risk as a determinant of the Ramadan effect. One might expect riskier loans to require greater cognitive effort from loan officers, and consequently, result in more decision mistakes by fatigued loan officers during Ramadan. Alternatively, loan officers could engage in charitable lending by being more lenient toward financially weaker borrowers during Ramadan, leading to worse than usual performance of riskier loans. The results in columns (4) and (5) do not lend support to these predictions, as we find that the Ramadan effect is not statistically significantly stronger for riskier loans. The interaction terms between Ramadan and internal risk rating in column (4) and collateral-to-loan ratio in column (5) are both statistically insignificant, although the sign of the coefficients is

\footnotetext{
${ }^{22}$ Based on the assumption that entrepreneurs would prefer to obtain longer maturity loans to fund new projects (since a short-term loan would lack the runway necessary for a new project to take off), we estimate another specification in which we further require a first-time loan to have a minimum maturity of 12 months and obtain nearly identical results.
} 
aligned with the aforementioned predictions.

Finally, the Ramadan effect could be seen as a byproduct of excess bank liquidity if there is a drop in lending opportunities during Ramadan, and in response, banks extend marginal loans that they otherwise would not extend outside of Ramadan. While it is difficult to assess this "equilibrium" mechanism conclusively, there are good reasons to doubt it. First, the summary statistics in Table I indicate little to no change in the observable characteristics of borrowers during Ramadan. Second, we plot average bank liquidity over the lunar calendar months in Figure 2 unless one takes the view that banks are able to quickly convert all of their excess liquidity into marginal loans, the plot shows no discernible sign of system-wide excess liquidity during Ramadan. Third, if banks were to have excess liquidity, they would be better off releasing it temporarily to short-term wholesale funding markets rather than keeping it and making marginal Ramadan loans - the gain from avoiding the extra default rate on Ramadan loans would more than offset the loss of loan spread for one month. Also, from a practical perspective, Ramadan is probably too brief of a treatment period for banks to change their lending policies. ${ }^{23}$

\section{G. Robustness}

Before concluding the paper, in Table XII, we address a collection of issues that are best described as robustness.

There are two major religious holidays in Islam: Eid Al-Fitr, which is celebrated at the end of Ramadan (ninth month of the lunar calendar), and Eid Al-Adha, which is celebrated on the tenth day of Dhu Hijjah (twelfth month of the lunar calendar). During Eid Al-Adha, as a symbol of Abraham's willingness to sacrifice his son, Muslims sacrifice a sheep, ram, goat, cow, or camel, depending on the region and the sacrificing individual's financial means. We examine whether the quality of credit decisions worsens before Eid Al-Adha, as it does before Eid Al-Fitr, to determine whether the Ramadan effect, rather than reflecting Ramadan observance, instead reflects general changes in credit decisions that occur before major religious holidays.

\footnotetext{
${ }^{23}$ Choudhary and Limodio (2018) use shocks to bank deposits induced by a Ramadan levy in Pakistan to study the impact of bank liquidity on lending. Turkey does not have a similar levy on bank deposits.
} 
In column (1), we present a specification in which the performance of loans originated in the month before Eid al-Adha is compared to the performance of loans originated in the remainder of the year. Controlling for the full set of borrower, loan, and macroeconomic characteristics together with month, year, loan purpose, and branch fixed effects, we find no significant effect of Eid al-Adha on loan performance, inconsistent with the hypothesis that the Ramadan effect is a general religious holiday effect. We do not draw any further inference based on this test about whether the main Ramadan finding is driven by physiological or charitable lending factors because the month before Eid Al-Adha features neither the fasting nor the charitable giving treatment that Ramadan provides.

In column (2), we split the month of Ramadan into three sub-periods: the first 10 days, the middle 10 days, and the last 10 days of Ramadan. We find that loans approved in all three subperiods of Ramadan are more likely to default than loans originated outside of Ramadan. This specification speaks to perhaps the most common type of reaction from readers who predict from either personal experience or casual intuition that the Ramadan effect should be strongest at the beginning or end of Ramadan, or peak somewhere in the middle. With many of the ideas having implications that are sometimes similar and sometimes working against each other, and without obvious proxies for them in our data set, it seems difficult to draw any strong conclusions. Nevertheless, it is interesting to consider several possibilities in light of the evidence that the Ramadan effect peaks in the middle of Ramadan. For example, one might expect loans approved earlier in Ramadan to perform worse as they are exposed to more days of impaired borrower effort due to fasting, but the inverse- $U$ pattern does not support that hypothesis. The pattern also does not support the notion that loans approved later in Ramadan perform worse due to an accumulation of fasting fatigue and the adverse effect of that accumulated fatigue on borrower and loan officer judgment.

In addition, if the Ramadan effect arises due to misconceived loan applications induced by borrower fatigue during Ramadan (assuming that loan officers cannot perfectly identify those applications), one might expect loans originated right after Ramadan to perform just as badly as loans originated during Ramadan, given some delay between loan application and approval. Figure 3 presents coefficient estimates from a regression explaining the default performance of 
small business loans by origination date in event time around Ramadan. The elevated probability of default continues for loans originated during the first 10 business days once Ramadan ends, consistent with the idea that the Ramadan effect is due to misconceived loan applications submitted during Ramadan. However, it is also possible that Ramadan-induced charitable feelings or fatigue of loan officers linger and lead to continued charitable lending for some time after Ramadan ends. Moreover, the sharp jump in the default probability of loans originated at the beginning of Ramadan is inconsistent with the "substitution" view in which loan officers make mistakes even before Ramadan starts as they speed up the loan approval process to shift work out of Ramadan. ${ }^{24}$

In column (3), we implement a lower loan size cutoff to focus on smaller business loans and further increase the probability that the sample includes loans that are approved by local loan officers and not by credit committees - based on our interviews with bank managers, lending limits of individual loan officers (i.e., maximum loan amount that a local loan officer is allowed to extend without approval from a credit committee) vary across banks, branches of the same bank, and over time. Specifically, we restrict the sample to loans with a principal amount below 100,000 TRY (deflated to 2008 prices) and find that in this sample, loans approved during Ramadan are more likely to default than loans approved in non-Ramadan months by 41.6 basis points, similar to the estimates in Table II.

In column (4), we exclude from the sample loans originated by bank branches located in Istanbul, Turkey's center of commerce and banking. Even though this reduces the sample size by about 35 percent, the coefficient estimate on Ramadan is strikingly similar to the estimates in Table II. In column (5), we exclude from the sample loans originated in financial crisis years 2007 and 2008. This appears to have some impact, but the coefficient estimate on Ramadan remains statistically and economically significant.

\section{Conclusion}

\footnotetext{
${ }^{24}$ Also inconsistent with the substitution view, we find that the performance of loans originated during Ramadan is significantly worse than the performance of loans originated in every other month of the Islamic lunar calendar.
} 
Using an administrative data set of bank loans originated in Turkey during 2003-2013, we examine the quality of credit decisions in the month of Ramadan, a period of heightened spiritual reflection and physiologically strenuous fasting without eating and drinking from dawn to sunset for practicing Muslims. Our main finding is that loans originated during Ramadan perform worse than loans originated outside of Ramadan. Our estimates of the Ramadan effect are economically large, indicating about 12 to 17 percent higher probability of default within two years of loan origination. Credit spreads at the time of loan origination are lower, not higher, despite the apparently higher credit risk of Ramadan loans.

Exploring two non-mutually exclusive channels that could work through physiology and spirituality, we find evidence in support of both. However, the evidence in favor of the spiritual channel is more suggestive in nature and less robust to different proxies of charitable lending. Tracing the physiological effects of fasting during Ramadan, we find that the Ramadan effect is greater for loans originated on warmer and longer summer days when loan officers do not reduce their workload.

Our findings underscore the importance of religion as a determinant of economic activity and growth (Barro and McCleary, 2003; McCleary and Barro, 2006; Campante and YanagizawaDrott, 2016). They also call for important policy work because Ramadan affects a significant fraction of the world population directly and the rest of the world population indirectly via international trade and investment decisions made by managers who observe the Ramadan. Academic research examining the effects of Ramadan on managerial judgment errors is scarce. We believe this is a fruitful area for future research across many disciplines. 


\section{REFERENCES}

Afifi, Z.E.M., 1997, Daily practices, study performance and health during the Ramadan fast, Journal of the Royal Society for the Promotion of Health 117, 231-235.

Almond, Douglas, and Bhashkar Mazumder, 2011, Health capital and the prenatal environment: The effect of Ramadan observance during pregnancy, American Economic Journal: Applied Economics 3, 56-85.

Almond, Douglas, Bhashkar Mazumder, and Reyn van Ewijk, 2015, In utero Ramadan exposure and children's academic performance, Economic Journal 125, 1501-1533.

Baele, Lieven, Moazzam Farooq, and Steven Ongena, 2014, Of religion and redemption: Evidence from default on Islamic loans, Journal of Banking $\mathcal{E}$ Finance 44, 141-159.

Barro, Robert J, and Rachel McCleary, 2003, Religion and economic growth across countries, American Sociological Review 68, 760-781.

Beck, Thorsten, Asli Demirgüç-Kunt, and Ouarda Merrouche, 2013, Islamic vs. conventional banking: Business model, efficiency and stability, Journal of Banking \& Finance 37, 433- 447.

Campante, Filipe, and David Yanagizawa-Drott, 2016, Does religion affect economic growth and happiness? Evidence from Ramadan, Quarterly Journal of Economics 29, 911-956.

Choudhary, M. Ali, and Nicola Limodio, 2018, Deposit volatility, liquidity and long-term investment: Evidence from a natural experiment in Pakistan, Bocconi University and State Bank of Pakistan Working Paper.

Corte's, Kristle, Ran Duchin, and Denis Sosyura, 2016, Clouded judgment: The role of sentiment in credit origination, Journal of Financial Economics 121, 392-413.

Danziger, Shai, Jonathan Levav, and Liora Avnaim-Pesso, 2011, Extraneous factors in judicial decisions, Proceedings of the National Academy of Sciences 108, 6889-6892.

Drexler, Alejandro, and Antoinette Schoar, 2014, Do relationships matter? Evidence from loan officer turnover, Management Science 60, 2722-2736.

Esposito, John L., ed., 2018, Oxford Islamic Studies Online (Oxford University Press, http://www.oxfordislamicstudies.com/article/opr/t125/e1859 (accessed 27-Jun-2018)).

Fisman, Raymond, Daniel Paravisini, and Vikrant Vig, 2017, Cultural proximity and loan outcomes, American Economic Review 107, 457-492.

Fogel, Robert W, 2004, Health, nutrition, and economic growth, Economic Development and Cultural Change 52, 643-658. 
Foster, Andrew, and Mark R Rosenzweig, 1994, A test for moral hazard in the labor market: Effort, health and calorie consumption, Review of Economics and Statistics 76, 213-227.

Foster, Andrew D, 1995, Nutrition and health investment, The American Economic Review 85, 148152.

Gailliot, Matthew T, and Roy F Baumeister, 2007, The physiology of willpower: Linking blood glucose to self-control, Personality and Social Psychology Review 11, 303-327.

Gailliot, Matthew T, Roy F Baumeister, C Nathan DeWall, Jon K Maner, E Ashby Plant, Di- anne M Tice, Lauren E Brewer, and Brandon J Schmeichel, 2007, Self-control relies on glucose as a limited energy source: Willpower is more than a metaphor., Journal of Personality and Social Psychology 92, 325-336.

Giovanni, J. D., Kalemli-Ozcan, S., Ulu, M. F., \& Baskaya, Y. S. (2019). International spillovers and local credit cycles. National Bureau of Economic Research Working Paper.

Glöckner, Andreas, 2016, The irrational hungry judge effect revisited: Simulations reveal that the magnitude of the effect is overestimated, Judgment and Decision Making 11, 601-610.

Guiso, Luigi, Paola Sapienza, and Luigi Zingales, 2003, People's opium? Religion and eco- nomic attitudes, Journal of Monetary Economics 50, 225-282.

Guiso, Luigi, Paola Sapienza, and Luigi Zingales, 2006, Does culture affect economic outcomes? Journal of Economic Perspectives 20, 23-48.

Hagger, M. S., N. L. D. Chatzisarantis, H. Alberts, C. O. Anggono, C. Batailler, A. R. Birt . ., and M. Zwienenberg, 2016, A multilab preregistered replication of the ego-depletion effect, Perspectives on Psychological Science 11, 546-573.

Heatherton, Todd F, and Dylan D Wagner, 2011, Cognitive neuroscience of self-regulation failure, Trends in Cognitive Sciences 15, 132-139.

Iannaccone, Laurence R, 1998, Introduction to the economics of religion, Journal of Economic Literature 36, 1465-1495.

Iverson, Benjamin, forthcoming, 2018, Get in line: Chapter 11 restructuring in crowded bankruptcy courts, Management Science 64, 5370-5394.

Iyers, Sriya, 2016, The new economics of religion, Journal of Economic Literature 54, 395-441.

Karaağaoğlu, Nilgün, and Sevinç, Yücecan, 2000, Some behavioural changes observed among fasting subjects, their nutritional habits and energy expenditure in Ramadan, International Journal of Food Sciences and Nutrition 51, 125-134.

Kuran, Timur, 2018, Islam and economic performance: Historical and contemporary links, Journal of Economic Literature 56, 1292-1359. 
Kurzban, Robert, 2010, Does the brain consume additional glucose during self-control tasks? Evolutionary Psychology 8, 244-259.

Leiper, John B, and AM Molla, 2003, Effects on health of fluid restriction during fasting in Ramadan, European Journal of Clinical Nutrition 57, S30-S38.

Majid, Muhammad Farhan, 2015, The persistent effects of in utero nutrition shocks over the life cycle: Evidence from Ramadan fasting, Journal of Development Economics 117, 48-57.

McCleary, Rachel M, and Robert J Barro, 2006, Religion and economy, Journal of Economic Perspectives 20, 49-72.

McNamara, Gerry, and Philip Bromiley, 1997, Decision making in an organizational set- ting: Cognitive and organizational influences on risk assessment in commercial lending, Academy of Management Journal 40, 1063-1088.

Muraven, Mark, Dianne M Tice, and Roy F Baumeister, 1998, Self-control as a limited re- source: Regulatory depletion patterns., Journal of Personality and Social Psychology 74, 774-789.

Peterson, Cameron R, and Lee R Beach, 1967, Man as an intuitive statistician., Psychological Bulletin $68,29-46$.

Sah, Raaj Kumar, and Joseph E Stiglitz, 1986, The architecture of economic systems: Hierarchies and polyarchies, American Economic Review 76, 716-727.

Schofield, Heather, 2014, The economic costs of low caloric intake: Evidence from India, Technical report, University of Pennsylvania.

Spurr, GB, 1983, Nutritional status and physical work capacity, American Journal of Physical Anthropology 26, 1-35.

Spurr, GB, 1988, Body size, physical work capacity, and productivity in hard work: Is bigger better? in Nestle Nutrition Workshop Series (USA).

Strauss, John, 1986, Does better nutrition raise farm productivity? Journal of Political Economy 94, 297-320.

Strauss, John, and Duncan Thomas, 1998, Health, nutrition, and economic development, Journal of Economic Literature 36, 766-817.

van Ewijk, Reyn, 2011, Long-term health effects on the next generation of Ramadan fasting during pregnancy, Journal of Health

Economics 30, 1246-1260. 


\section{Appendix A. Definitions of Key Variables}

Default: When contractual payments on a loan are 90+ days past due or when future payments are not expected to be received in full, banks classify the loan as non-performing and send an overdue notification to the borrower to request repayment of the loan balance as well as any accrued interest and fees in full within seven days after the receipt of notification. If no payment is made, the bank initiates an administrative investigation which involves negotiations with the borrower for a possible restructuring. During this process, the bank imposes default interest rate and reports the loan's status to the credit registry. If the restructuring fails, the bank initiates legal action. Sometimes legal action is initiated without a restructuring attempt. Our data set includes a column that shows the earliest date on which the bank initiates administrative investigation or legal action. We consider this date as the default date of the loan. We create a dummy variable, Default, that equals one if an event of default occurs at any point within two years after loan origination; and zero otherwise.

Ramadan: We obtain Ramadan days in the Gregorian calendar from the Presidency of Religious Affairs (PRA). The table below shows the first and last days of Ramadan by calendar (Gregorian) year. Ramadan calendar is not universal: Muslims in Middle Eastern countries begin fasting after they see the crescent of the new moon with a naked eye. Muslims in Turkey, on the other hand, generally determine the beginning of Ramadan based on the moon's state of alignment with the earth. The difference in traditions sometimes leads Turks to start and end fasting one day earlier or later.

\begin{tabular}{rrr}
\hline Year & $\begin{array}{r}\text { First Day of } \\
\text { Ramadan }\end{array}$ & $\begin{array}{r}\text { Last day of } \\
\text { Ramadan }\end{array}$ \\
\hline 2003 & 27 October & 24 November \\
2004 & 15 October & 13 November \\
2005 & 5 October & 2 November \\
2006 & 24 September & 22 October \\
2007 & 13 September & 11 October \\
2008 & 1 September & 29 September \\
2009 & 21 August & 19 September \\
2010 & 11 August & 8 September \\
2011 & 1 August & 29 August \\
2012 & 20 July & 18 August \\
2013 & 9 July & 7 August \\
\hline
\end{tabular}

Interest rate: At conventional banks, interest rate equals the annual rate of interest on the loan. For floating rate loans, the interest rate is calculated as the sum of the interest spread and the level of 
the floating base at the end of the month of origination. At participation banks, the interest rate is the annualized nominal yield (or internal rate of return) of scheduled future loan payments including fees at origination. We adjust interest rates with the monthly consumer price index. Discount points and front-loaded fees are uncommon in Turkey. While prepayment penalties do exist, they are often waived for business borrowers that refinance with the same bank and are not systematically reported to our data provider.

Loan spread: The difference, at loan origination, between the nominal interest rate on the loan and the annualized daily yield of the Treasury bond with the closest maturity date. We obtain data on Treasury yields from the Central Bank of the Republic of Turkey.

Regulatory risk weight (loan): Banks calculate the appropriate risk weight of a loan based on standards published in Basel I and Basel II and guidelines provided by the Banking Regulation and Supervisory Agency (BRSA). The risk weight is used to calculate the minimum amount of capital that the bank must hold against a loan.

Marginal loan: Indicator variable equal to one if regulatory risk weight of the loan exceeds 100 percent.

Ln (loan amount): The natural logarithm of loan principal amount at origination in thousands of Turkish Liras deflated to 2008 prices using the monthly consumer price index.

Collateral-to-loan ratio (\%): Total amount of collateral protection received by the lender divided by loan principal amount (both at origination).

Stated maturity: Number of months between the origination date and the stated-maturity date.

FX-denominated: An indicator variable that equals 0 if the loan is denominated in Turkish liras; and 1 if it is denominated in foreign currencies.

Internal risk rating (borrower): Internal risk rating is a five-scale rating assigned by the bank to each borrower to indicate the bank's assessment of the borrower's financial strength: 1 . Very strong financial condition; 2. Good financial condition; 3. Short- and medium-term risks; 4 . Very high short-term risks; 5. Default. Internal risk rating is missing for all loans originated before 2007. In regressions that use this variable, we include an indicator variable that equals one if the internal risk rating is missing.

Marginal borrower: Indicator variable equal to one if the borrower had a default in the past three 
years.

First-time loan (borrower): Indicator variable equal to one for a borrower's first loan in the data set. Set to missing for calendar years 2003 and 2004.

Past client at branch: Indicator variable equal to one if the borrower obtained a loan in the past from the same bank branch.

Branch busyness: The natural logarithm of one plus the number of small business loans granted by the bank branch on a given day.

Small city: Dummy variable that is equal to one if the average population of a city during 20072013 is above one million, and zero otherwise.

Number of borrowers: Natural logarithm of the number of unique borrowers of in a branch-month.

Bank capital adequacy ratio: Regulatory capital-to-risk weighted assets ratio reported by banks following the standards published in Basel I and II, and guidelines provided by the Banking Regulation and Supervisory Agency (BRSA).

Bank liquidity ratio: Ratio of a bank's liquid assets to total assets, where liquid assets include cash holdings, receivables from the Central Bank, money markets, and banks, net securities held for trading and sale, required reserves, and receivables from inter-bank securities and reverse repurchase agreements.

Summer: Indicator variable equal to one if the loan is originated in June, July, or August.

Temperature: Average local temperature at the province level over a three-day period ending on the day of loan origination. Data on maximum daily temperature come from the Turkish State Meteorological Service. Temperature data are missing for slightly more than $50 \%$ of the branchdays before 2008 , about $40 \%$ of the branch-days in 2009 , and less than $5 \%$ of the branch-days from 2010-2013.

Macro control: Beginning-of-month value of the VIX index that is reported by the Chicago Board of Exchange (CBOE). The VIX is a real-time market index representing the market's expectations for volatility over the coming 30 days. Giovanni et al. (2019) find that $43 \%$ of the variation in aggregate bank loan supply in Turkey during 2003-2013 can be explained by variations in the VIX index. 
Eid-al Adha ("Festival of the Sacrifice"): Eid-al Adha is an Islamic holiday, celebrated two months and ten days after the last day of Ramadan. In the Islamic lunar calendar, Eid al-Adha begins on the 10th day of Dhu al-Hijjah and lasts for four days. 
Figure 1. Daily Schedule for a Muslim Observing the Ramadan in Istanbul in August

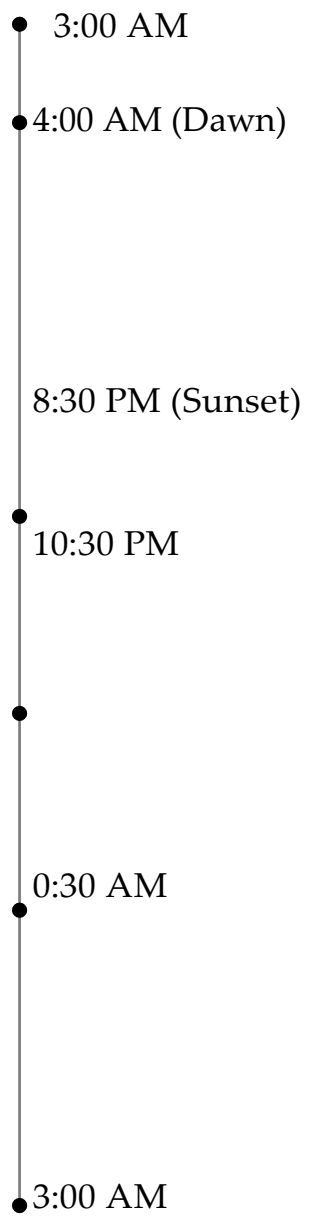

Suhoor: Meal before fast begins

Sawm or fasting for approximately 16.5 hours

Iftar: Fast breaking meal

Taraweeh: Supererogatory prayer with congregation

Sleep 
Figure 2. Average Bank Liquidity by Islamic Lunar Month

\subsection{5}

0.33

0.31

0.29

0.27

0.25
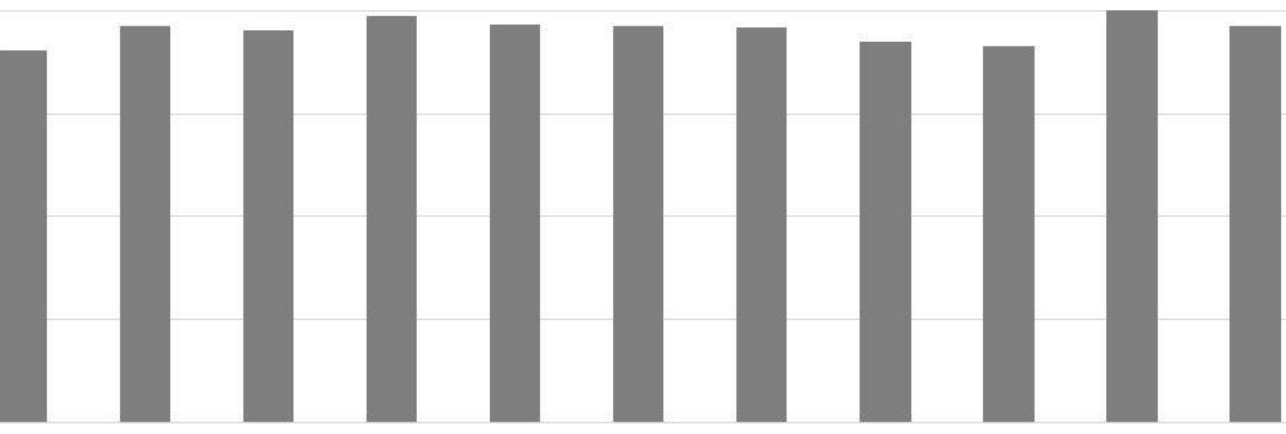

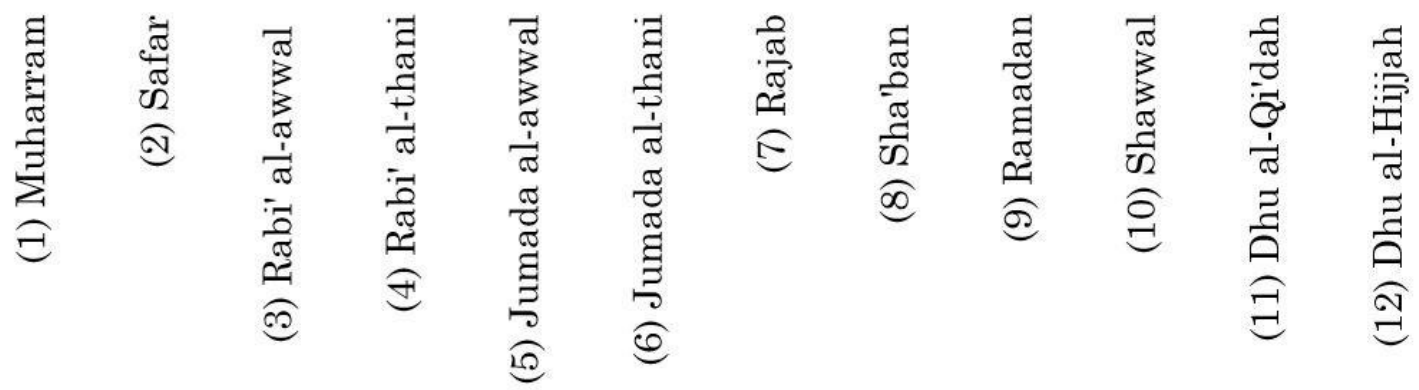

This figure shows the average bank liquidity ratio (the ratio of liquid assets, as defined in the Appendix, to book value of total bank assets) for each Islamic lunar month over the period 2003-2013. 


\section{Figure 3. Risk-Adjusted Default Rates (\%) Relative to the Middle 10 Days of Ramadan}

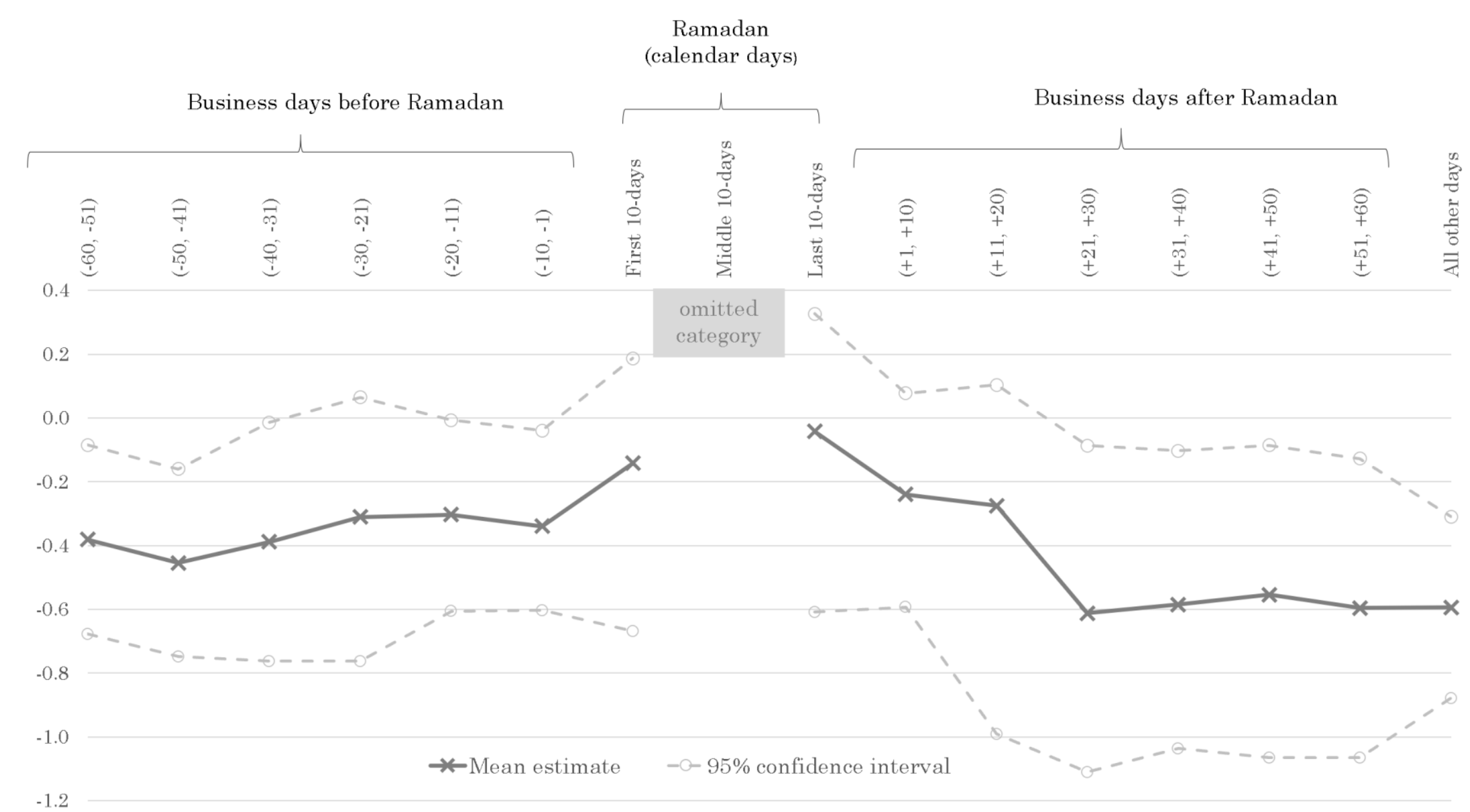

This figure presents coefficient estimates from a regression explaining default of small business loans by origination date in event time around Ramadan. The regression includes month, year, loan purpose and branch fixed effects, and loan and borrower characteristics. The middle 10 days of Ramadan is the omitted category and there are indicator variables for the first and last 10 days of Ramadan, up to 60 business days before and after Ramadan for each 10-business day interval, and the rest of the lunar calendar. 
Table I. Summary Statistics

This table presents summary statistics for small business loans granted by private banks in Turkey during the period 2003-2013. Small business loans are defined as loans with a principal amount of one million Turkish Liras or less (deflated to 2008 prices using the monthly Consumer Price Index obtained from the Central Bank of the Republic of Turkey). The table also presents summary statistics separately for loans originated during Ramadan (middle panel) and loans originated outside of Ramadan (right panel). Variable definitions are provided in Appendix A

\begin{tabular}{|c|c|c|c|c|c|c|}
\hline \multirow{5}{*}{$\begin{array}{l}N \text { unique bank-branches } \\
N \text { unique borrowers } \\
N \text { loans }\end{array}$} & \multicolumn{2}{|c|}{$\begin{array}{c}\text { All } \\
\text { loans }\end{array}$} & \multicolumn{2}{|c|}{$\begin{array}{c}\text { Ramadan } \\
\text { loans }\end{array}$} & \multicolumn{2}{|c|}{$\begin{array}{l}\text { Non-Ramadan } \\
\text { Loans }\end{array}$} \\
\hline & \multicolumn{2}{|c|}{9,578} & \multicolumn{2}{|c|}{9,365} & \multicolumn{2}{|c|}{9,564} \\
\hline & \multicolumn{2}{|c|}{$1,329,032$} & \multicolumn{2}{|c|}{340,470} & \multicolumn{2}{|c|}{$1,291,411$} \\
\hline & \multicolumn{2}{|c|}{$16,101,481$} & \multicolumn{2}{|c|}{$1,276,045$} & \multicolumn{2}{|c|}{$14,825,436$} \\
\hline & Mean & S.D. & Mean & S.D. & Mean & S.D. \\
\hline $100 *$ Default & 2.34 & 15.11 & 2.69 & 16.17 & 2.31 & 15.01 \\
\hline $100 *$ Ramadan & 7.93 & 27.01 & 100.00 & 0.00 & 0.00 & 0.00 \\
\hline \multicolumn{7}{|l|}{ Loan characteristics: } \\
\hline Interest rate $(\%)$ & 7.50 & 12.76 & 7.22 & 12.35 & 7.52 & 12.79 \\
\hline $100 *$ Zero interest rate & 3.71 & 18.9 & 2.99 & 17.02 & 3.77 & 19.05 \\
\hline Loan spread (\%) & 4.70 & 14.34 & 4.26 & 13.82 & 4.74 & 14.38 \\
\hline $100 *$ Regulatory risk weight (loan) & 76.60 & 40.02 & 75.76 & 40.24 & 76.67 & 40.00 \\
\hline $100 *$ Marginal loan & 2.78 & 16.43 & 2.79 & 16.48 & 2.78 & 16.43 \\
\hline Ln (loan amount) & 3.38 & 1.48 & 3.40 & 1.47 & 3.37 & 1.48 \\
\hline Collateral-to-loan ratio (\%) & 84.50 & 79.63 & 84.55 & 79.74 & 84.50 & 79.62 \\
\hline Stated maturity (month) & 21.40 & 21.65 & 20.74 & 20.92 & 21.46 & 21.71 \\
\hline $100 *$ FX-denominated & 9.22 & 28.93 & 10.10 & 30.13 & 9.14 & 28.82 \\
\hline \multicolumn{7}{|l|}{ Borrower characteristics: } \\
\hline Internal risk rating (borrower) & 2.57 & 1.00 & 2.60 & 1.02 & 2.57 & 1.00 \\
\hline $100 *$ Marginal borrower & 0.71 & 8.40 & 0.69 & 8.28 & 0.71 & 8.41 \\
\hline $100 *$ First-time loan (borrower) & 12.12 & 32.63 & 11.36 & 31.73 & 12.18 & 32.71 \\
\hline $100 *$ Past client at branch & 73.20 & 44.29 & 72.72 & 44.54 & 73.25 & 44.27 \\
\hline \multicolumn{7}{|l|}{ Lender characteristics: } \\
\hline Branch busyness & 1.67 & 0.94 & 1.54 & 0.78 & 1.68 & 0.96 \\
\hline Number of borrowers & 3.35 & 1.05 & 3.21 & 0.97 & 3.36 & 1.06 \\
\hline $100 *$ Small city & 8.81 & 28.34 & 8.22 & 27.47 & 8.86 & 28.41 \\
\hline Bank capital adequacy ratio (\%) & 16.21 & 3.04 & 15.97 & 2.95 & 16.23 & 3.05 \\
\hline Bank liquidity ratio (\%) & 28.57 & 9.01 & 28.20 & 8.85 & 28.61 & 9.03 \\
\hline \multicolumn{7}{|l|}{ Fasting intensity measures: } \\
\hline $100 *$ Summer & 23.85 & 42.62 & 53.18 & 49.90 & 21.33 & 40.96 \\
\hline Temperature $\left({ }^{\circ} \mathrm{C}\right)$ & 20.56 & 8.95 & 29.78 & 5.23 & 19.78 & 8.77 \\
\hline \multicolumn{7}{|l|}{ Other variables: } \\
\hline Macro control (VIX index) & 20.84 & 8.45 & 20.22 & 4.53 & 20.90 & 8.70 \\
\hline $100 *$ Eid al-Adha & 8.97 & 28.58 & 0.00 & 0.00 & 9.75 & 29.66 \\
\hline
\end{tabular}


Table II. The Effect of Ramadan on the Likelihood of Default: Small Business Loans

We estimate linear probability models that show the effect of Ramadan on the default rates of small business loans. Our sample consists of all small business loans granted by private banks in Turkey during 2003-2013. The dependent variable, Default, is a binary variable indicating borrower nonperformance (either following 90+ days delinquency or when future contractual payments become suspect) within two years after loan origination. Columns (1) to (6) present regression results for the full sample whereas Column (7) presents regression results for loans originated on calendar days (July 9 to November 24) that featured Ramadan fasting at least once during the sample period. Regressions include controls for the CBOE VIX index, borrower and loan characteristics as well as month, year, loan purpose, and branch fixed effects as indicated in each column. Borrower and loan characteristics include indicators for the internal risk rating of the borrower, regulatory (Basel) risk weight of the loan, loan interest rate (adjusted for inflation), a zero interest rate dummy, collateral-to-principal ratio, the natural logarithm of loan principal amount (deflated to 2008 prices), loan maturity (in months), and an indicator variable for whether the loan is denominated in a foreign currency. Standard errors that are heteroskedasticity-consistent and clustered at the month-year level are reported in parentheses beneath coefficient estimates. ${ }^{* * *},{ }^{* *}$, or $^{*}$ indicates that the coefficient estimate is significant at the $1 \%, 5 \%$, or $10 \%$ level, respectively.

\begin{tabular}{|c|c|c|c|c|c|c|c|}
\hline & \multicolumn{7}{|c|}{$100 \times \operatorname{Prob}($ Default=1) } \\
\hline & \multicolumn{6}{|c|}{ Full sample } & \multirow{2}{*}{$\begin{array}{c}\text { Days spanned by } \\
\text { Ramadan } \\
(7)\end{array}$} \\
\hline & $(1)$ & $(2)$ & $(3)$ & $(4)$ & (5) & $(6)$ & \\
\hline Ramadan & $\begin{array}{c}0.397^{* * *} \\
(0.116)\end{array}$ & $\begin{array}{l}0.315^{* *} \\
(0.128)\end{array}$ & $\begin{array}{c}0.357^{* * *} \\
(0.113)\end{array}$ & $\begin{array}{c}0.327^{* * *} \\
(0.115)\end{array}$ & $\begin{array}{c}0.339^{* * *} \\
(0.118)\end{array}$ & $\begin{array}{l}0.282^{* *} \\
(0.127)\end{array}$ & $\begin{array}{c}0.322^{* * *} \\
(0.078)\end{array}$ \\
\hline Year FEs & Yes & Yes & Yes & Yes & No & Yes & Yes \\
\hline Month FEs & Yes & Yes & Yes & No & Yes & Yes & Yes \\
\hline Macro control & Yes & Yes & Yes & Yes & Yes & Yes & Yes \\
\hline Borrower/loan characteristics & No & Yes & Yes & Yes & Yes & Yes & Yes \\
\hline Loan purpose FEs & No & Yes & Yes & Yes & Yes & Yes & Yes \\
\hline Branch FEs & No & No & Yes & No & No & Yes & Yes \\
\hline Branch $x$ Month FEs & No & No & No & Yes & No & No & No \\
\hline Branch x Year FEs & No & No & No & No & Yes & No & No \\
\hline Borrower FEs & No & No & No & No & No & Yes & No \\
\hline$\overline{\mathrm{N}}$ & $16,101,481$ & $16,101,481$ & $16,101,481$ & $16,101,481$ & $16,101,481$ & $16,101,481$ & $5,694,183$ \\
\hline$R^{2}$ & 0.01 & 0.21 & 0.27 & 0.28 & 0.35 & 0.46 & 0.29 \\
\hline
\end{tabular}




\section{Table III. The Effect of Ramadan on the Likelihood of Default by Calendar Year}

We estimate linear probability models, separately for each calendar year, to estimate the effect of Ramadan on the default rates of small business loans. We use the same set of control variables in Column (3) of Table II, except for year and month fixed effects. Standard errors that are heteroskedasticity-consistent are reported in parentheses beneath coefficient estimates. ${ }^{* * *}, * *$, or ${ }^{*}$ indicates that the coefficient estimate is significant at the $1 \%, 5 \%$, or $10 \%$ level, respectively.

\begin{tabular}{|c|c|c|c|c|c|c|c|c|c|c|c|c|}
\hline & \multicolumn{12}{|c|}{$100 \times \operatorname{Prob}($ Default=1) } \\
\hline & \multicolumn{12}{|c|}{ Calendar year: } \\
\hline & $\begin{array}{c}2003 \\
(1) \\
\end{array}$ & $\begin{array}{c}2004 \\
(2) \\
\end{array}$ & $\begin{array}{c}2005 \\
(3) \\
\end{array}$ & $\begin{array}{c}2006 \\
(4) \\
\end{array}$ & $\begin{array}{c}2007 \\
(5) \\
\end{array}$ & $\begin{array}{c}2008 \\
(6) \\
\end{array}$ & $\begin{array}{c}2009 \\
(7) \\
\end{array}$ & $\begin{array}{c}2010 \\
(8) \\
\end{array}$ & $\begin{array}{c}2011 \\
(9) \\
\end{array}$ & $\begin{array}{c}2012 \\
(10) \\
\end{array}$ & $\begin{array}{c}2013 \\
(11) \\
\end{array}$ & $\begin{array}{c}\text { Mean } \\
\text { coefficient }\end{array}$ \\
\hline Ramadan & $\begin{array}{c}0.053 \\
(0.073)\end{array}$ & $\begin{array}{c}0.386^{* * *} \\
(0.066)\end{array}$ & $\begin{array}{c}0.121^{* * *} \\
(0.044)\end{array}$ & $\begin{array}{l}-0.057 \\
(0.050)\end{array}$ & $\begin{array}{l}0.097^{*} \\
(0.051)\end{array}$ & $\begin{array}{c}0.133^{* * *} \\
(0.040)\end{array}$ & $\begin{array}{c}0.269^{* * *} \\
(0.031)\end{array}$ & $\begin{array}{c}0.257^{* * *} \\
(0.031)\end{array}$ & $\begin{array}{c}0.762^{* * *} \\
(0.041)\end{array}$ & $\begin{array}{l}-0.038 \\
(0.033)\end{array}$ & $\begin{array}{c}0.119^{* * *} \\
(0.020)\end{array}$ & $\begin{array}{l}0.191^{* *} \\
(0.086)\end{array}$ \\
\hline Macro control & Yes & Yes & Yes & Yes & Yes & Yes & Yes & Yes & Yes & Yes & Yes & \\
\hline Borrower/loan char. & Yes & Yes & Yes & Yes & Yes & Yes & Yes & Yes & Yes & Yes & Yes & \\
\hline Loan purpose FEs & Yes & Yes & Yes & Yes & Yes & Yes & Yes & Yes & Yes & Yes & Yes & \\
\hline Branch FEs & Yes & Yes & Yes & Yes & Yes & Yes & Yes & Yes & Yes & Yes & Yes & \\
\hline$\overline{\mathrm{N}}$ & 236,788 & 484,456 & 779,493 & 905,154 & $1,199,160$ & $1,507,936$ & $1,764,942$ & $2,020,465$ & $2,101,071$ & $2,467,548$ & $2,632,040$ & \\
\hline$R^{2}$ & 0.25 & 0.25 & 0.11 & 0.24 & 0.37 & 0.37 & 0.42 & 0.34 & 0.38 & 0.43 & 0.36 & \\
\hline
\end{tabular}




\section{Table IV. The Effect of Ramadan on the Likelihood of Default by Calendar Month}

We test whether the effect of Ramadan on the default rates of small business loans varies with calendar month of loan origination by estimating a linear probability model separately for each calendar month that features Ramadan fasting during our sample period. We use the same set of control variables in Column (3) of Table II. Standard errors that are heteroskedasticity-consistent in columns (1) to (5) and clustered at the month-year level are reported in parentheses beneath coefficient estimates. ${ }^{* * *},{ }^{* *}$, or ${ }^{*}$ indicates that the coefficient estimate is significant at the $1 \%$, $5 \%$, or $10 \%$ level, respectively.

\begin{tabular}{lccccc}
\hline & July & August & September & October & November \\
& $(1)$ & $(2)$ & $(3)$ & $(4)$ & $(5)$ \\
\hline \multirow{4}{*}{ Ramadan } & & & & & \\
& $0.093^{* *}$ & $0.108^{* * *}$ & $0.127^{* * *}$ & -0.016 & $1.041^{* * *}$ \\
Year FEs & $(0.047)$ & $(0.034)$ & $(0.039)$ & $(0.063)$ & $(0.100)$ \\
Macro control & Yes & Yes & Yes & Yes & Yes \\
Borrower/loan characteristics & Yes & Yes & Yes & Yes & Yes \\
Loan purpose FEs & Yes & Yes & Yes & Yes & Yes \\
Branch FEs & Yes & Yes & Yes & Yes & Yes \\
\hline $\mathrm{N}$ & Yes & Yes & Yes & Yes & Yes \\
$R^{2}$ & $1,122,488$ & $1,174,258$ & $1,489,172$ & $1,224,624$ & $1,266,313$ \\
\hline
\end{tabular}


Table V. Ramadan Loans and Likelihood of Default by Loan Type

We estimate linear probability models that show the effect of Ramadan on the default rates of different kinds of business and personal loans. Standard errors that are heteroskedasticity-consistent and clustered at the month-year level are reported in parentheses beneath coefficient estimates. ${ }^{* * *},{ }^{* *}$, or ${ }^{*}$ indicates that the coefficient estimate is significant at the $1 \%, 5 \%$, or $10 \%$ level, respectively.

\begin{tabular}{lccccc}
\hline & \multicolumn{4}{c}{$100 \times$ Prob(Default=1) } \\
\cline { 2 - 3 } & \multicolumn{2}{c}{ Business loans } & & \multicolumn{2}{c}{ Personal loans } \\
\cline { 2 - 3 } \cline { 5 - 6 } & Medium & Large & & Mortgage & Auto \\
& $(1)$ & $(2)$ & & $(3)$ & $(4)$ \\
\hline Ramadan & 0.009 & 0.026 & & $-0.180^{*}$ & -0.002 \\
& $(0.070)$ & $(0.140)$ & & $(0.098)$ & $(0.146)$ \\
Year FEs & Yes & Yes & & Yes & Yes \\
Month FEs & Yes & Yes & & Yes & Yes \\
Macro control & Yes & Yes & & Yes & Yes \\
Borrower/loan characteristics & Yes & Yes & & Yes & Yes \\
Loan purpose FEs & Yes & Yes & & Yes & Yes \\
Branch FEs & Yes & Yes & & Yes & Yes \\
\hline $\mathrm{N}$ & 338,896 & 25,191 & & $1,802,408$ & 391,789 \\
$R^{2}$ & 0.12 & 0.25 & & 0.21 & 0.50 \\
\hline
\end{tabular}


Table VI. The Effect of Ramadan on Credit Spreads and Collateral

This table presents estimates from regressions explaining credit spreads (columns (1) and (2)), collateral-to-loan ratio (columns (3) and (4)), and collateral indicator (columns (5) and (6)) of small business loans in the period 2003-2013. Foreign currency denominated loans and loans with nonpositive credit spreads are excluded in columns (1) and (2). Differently from Tables II to V, borrower and loan controls do not include interest rate in columns (1) and (2) and collateral-to-loan ratio in columns (3) to (6). Standard errors that are heteroskedasticity-consistent and clustered at the month-year level are reported in parentheses beneath coefficient estimates. ${ }^{* * *},{ }^{* *}$, or ${ }^{*}$ indicates that the coefficient estimate is significant at the $1 \%$, $5 \%$, or $10 \%$ level, respectively.

\begin{tabular}{|c|c|c|c|c|c|c|}
\hline & \multicolumn{2}{|c|}{ Credit spread (\%) } & \multicolumn{2}{|c|}{ Collateral-to-loan ratio } & \multicolumn{2}{|c|}{$\operatorname{Pr}($ Collateral $>0)$} \\
\hline & $(1)$ & $(2)$ & $(3)$ & $(4)$ & $(5)$ & $(6)$ \\
\hline \multirow[t]{2}{*}{ Ramadan } & -0.288 & -0.281 & $0.016^{* *}$ & $0.013^{*}$ & $0.008^{*}$ & 0.007 \\
\hline & $(0.297)$ & $(0.284)$ & $(0.007)$ & $(0.007)$ & $(0.005)$ & $(0.005)$ \\
\hline Year FEs & Yes & Yes & Yes & Yes & Yes & Yes \\
\hline Month FEs & Yes & Yes & Yes & Yes & Yes & Yes \\
\hline Macro control & Yes & Yes & Yes & Yes & Yes & Yes \\
\hline Borrower/loan characteristics & No & Yes & No & Yes & No & Yes \\
\hline Loan purpose FEs & Yes & Yes & Yes & Yes & Yes & Yes \\
\hline Branch FEs & Yes & Yes & Yes & Yes & Yes & Yes \\
\hline $\mathrm{N}$ & \multicolumn{2}{|c|}{$11,219,248$} & \multicolumn{2}{|c|}{$16,101,481$} & \multicolumn{2}{|c|}{$16,101,481$} \\
\hline$R^{2}$ & 0.23 & 0.34 & 0.26 & 0.29 & 0.35 & 0.38 \\
\hline
\end{tabular}


Table VII. Branch-Level Daily Loan Volume and the Difficulty of Fasting

This table presents estimates from regressions explaining how branch-level daily volume of small business loans varies with difficulty of fasting in the period 2003-2013. Loan volume is the natural logarithm of one plus the total number of small business loans originated at a bank branch location on a given day. In column (2), our proxy for difficulty of fasting is the average local temperature (in degrees Celsius) over three days. We measure temperate over a three-day window to capture conditions experienced during loan processing. In column (3), our proxy for difficulty of fasting is an indicator variable for summer (June, July, August). All regressions include controls for daily averages of loan rate, maturity, amount, and risk weight (weighted by loan amount) as well as year and branch fixed effects. Standard errors that are heteroskedasticity- consistent and clustered at the month-year level are reported in parentheses beneath coefficient estimates. ${ }^{* * *},{ }^{* *}$, or $^{*}$ indicates that the coefficient estimate is significant at the $1 \%, 5 \%$, or $10 \%$ level, respectively.

\begin{tabular}{lccc}
\hline & \multicolumn{3}{c}{ Branch busyness } \\
\cline { 2 - 4 } & & \multicolumn{2}{c}{ Intensity measure } \\
& & Local & Summer \\
& $(1)$ & temperature & dummy \\
\hline Ramadan & -0.003 & $0.013^{*}$ & $(3)$ \\
Ramadan x Intensity & $(0.003)$ & $(0.008)$ & 0.003 \\
& & $-0.001^{*}$ & $(0.004)$ \\
100 x Intensity & & $(0.000)$ & $-0.014^{* *}$ \\
& & $-0.036^{* *}$ & $(0.006)$ \\
Borrower/Loan characteristics & & $(0.018)$ & 0.354 \\
Year FEs & Yes & Yes & $(0.307)$ \\
Branch FEs & Yes & Yes & Yes \\
\hline Unit of observation & Yes & Yes & Yes \\
$\mathrm{N}$ & Branch-day & Branch-day & Yes \\
$R^{2}$ & $27,132,765$ & $18,769,253$ & $27,132,765$ \\
\hline
\end{tabular}


Table VIII. The Effect of Ramadan on Loan Performance by Branch Busyness

We test whether the effect of Ramadan on the default rates of small business loans varies with branch busyness. We divide loans by each branch within a year into four quartiles based on the total number of small business loans originated by the branch on the loan date. Next, we pool loan data from all the branchyears and estimate default models separately for each quartile. We use the same set of control variables as in Column (3) of Table II. Standard errors that are heteroskedasticity-consistent and clustered at the monthyear level are reported in parentheses beneath coefficient estimates. ${ }^{* * *},{ }^{* *}$, or $^{*}$ indicates that the coefficient estimate is significant at the $1 \%, 5 \%$, or $10 \%$ level, respectively.

\begin{tabular}{lcccc}
\hline & \multicolumn{4}{c}{ Branch busyness quartile } \\
\cline { 2 - 5 } & Q1 (low) & Q2 & Q3 & Q4 (high) \\
& $(1)$ & $(2)$ & $(3)$ & $(4)$ \\
\hline Ramadan & $0.190^{*}$ & $0.265^{* *}$ & $0.365^{* * *}$ & $0.648^{* * *}$ \\
& $(0.103)$ & $(0.113)$ & $(0.134)$ & $(0.137)$ \\
Year FEs & Yes & Yes & Yes & Yes \\
Month FEs & Yes & Yes & Yes & Yes \\
Macro control & Yes & Yes & Yes & Yes \\
Borrower/loan characteristics & Yes & Yes & Yes & Yes \\
Loan purpose FEs & Yes & Yes & Yes & Yes \\
Branch FEs & Yes & Yes & Yes & Yes \\
\hline $\mathrm{N}$ & $5,817,699$ & $3,702,413$ & $3,467,857$ & $3,113,512$ \\
$R^{2}$ & 0.32 & 0.29 & 0.27 & 0.23 \\
\hline
\end{tabular}




\section{Table IX. Loan Default and Difficulty of Fasting at Origination}

This table presents estimates from regressions explaining how default of small business loans varies with difficulty of fasting at origination in the period 2003-2013. The sample includes all bank branches in columns (1) and (3); and busiest days for a branch within a year (top busyness quartile as defined in Table VIII) in columns (2) and (4). Standard errors that are heteroskedasticity-consistent and clustered at the month-year level are reported in parentheses beneath coefficient estimates. ${ }^{* * *},{ }^{* *}$, or ${ }^{*}$ indicates that the coefficient estimate is significant at the $1 \%, 5 \%$, or $10 \%$ level, respectively.

\begin{tabular}{|c|c|c|c|c|}
\hline & \multicolumn{4}{|c|}{$100 \times \operatorname{Prob}($ Default $=1)$} \\
\hline & \multicolumn{4}{|c|}{ Intensity measure: } \\
\hline & \multicolumn{2}{|c|}{ Local temperature } & \multicolumn{2}{|c|}{ Summer dummy } \\
\hline & $(1)$ & $(2)$ & (3) & $(4)$ \\
\hline \multirow[t]{2}{*}{ Ramadan } & 0.089 & 0.307 & $0.194^{*}$ & $0.306^{*}$ \\
\hline & $(0.131)$ & $(0.198)$ & $(0.114)$ & $(0.161)$ \\
\hline \multirow[t]{2}{*}{ Intensity } & -0.002 & 0.002 & 0.021 & -0.017 \\
\hline & $(0.009)$ & $(0.012)$ & $(0.100)$ & $(0.169)$ \\
\hline \multirow[t]{2}{*}{ Ramadan x Intensity } & $0.021^{*}$ & $0.036^{*}$ & 0.191 & $0.737^{* *}$ \\
\hline & $(0.012)$ & $(0.019)$ & $(0.163)$ & $(0.282)$ \\
\hline \multirow[t]{2}{*}{ Branch busyness } & $-0.872^{* * *}$ & & $-0.768^{* * *}$ & \\
\hline & $(0.092)$ & & $(0.093)$ & \\
\hline \multirow[t]{2}{*}{ Intensity x Branch busyness } & 0.010 & & -0.181 & \\
\hline & $(0.008)$ & & $(0.114)$ & \\
\hline \multirow[t]{2}{*}{ Ramadan x Branch busyness } & $-0.370^{* *}$ & & -0.157 & \\
\hline & $(0.182)$ & & $(0.139)$ & \\
\hline \multirow[t]{2}{*}{ Ramadan $x$ Intensity $x$ Branch busyness } & $0.045^{* *}$ & & $0.803^{* *}$ & \\
\hline & $(0.021)$ & & $(0.334)$ & \\
\hline Year FEs & Yes & Yes & Yes & Yes \\
\hline Macro control & Yes & Yes & Yes & Yes \\
\hline Borrower/loan characteristics & Yes & Yes & Yes & Yes \\
\hline Loan purpose FEs & Yes & Yes & Yes & Yes \\
\hline Branch FEs & Yes & Yes & Yes & Yes \\
\hline$\overline{\mathrm{N}}$ & $13,477,960$ & $2,618,053$ & $16,101,481$ & $3,113,552$ \\
\hline$R^{2}$ & 0.28 & 0.23 & 0.27 & 0.23 \\
\hline
\end{tabular}




\section{Table X. Charitable Lending in Ramadan}

This table presents estimates from regressions explaining how default of small business loans varies for loans that resemble charitable lending in the period 2003-2013. Proxies for charitable lending are based on borrower and lender acquaintance (past client indicator in column (1)), and lender financial strength (bank liquidity ratio in column (3) and bank capital adequacy ratio in columns (3), (4) and (5)). The sample is restricted to loans at conventional banks in column (4) and secured loans with a collateral-to-loan ratio of at least $100 \%$ or more in column (5). The regressions include the same set of control variables in Column (3) of Table II. Standard errors that are heteroskedasticity-consistent and clustered at the month-year level are reported in parentheses beneath coefficient estimates. ${ }^{* * *}, * *$, or ${ }^{*}$ indicates that the coefficient estimate is significant at the $1 \%, 5 \%$, or $10 \%$ level, respectively.

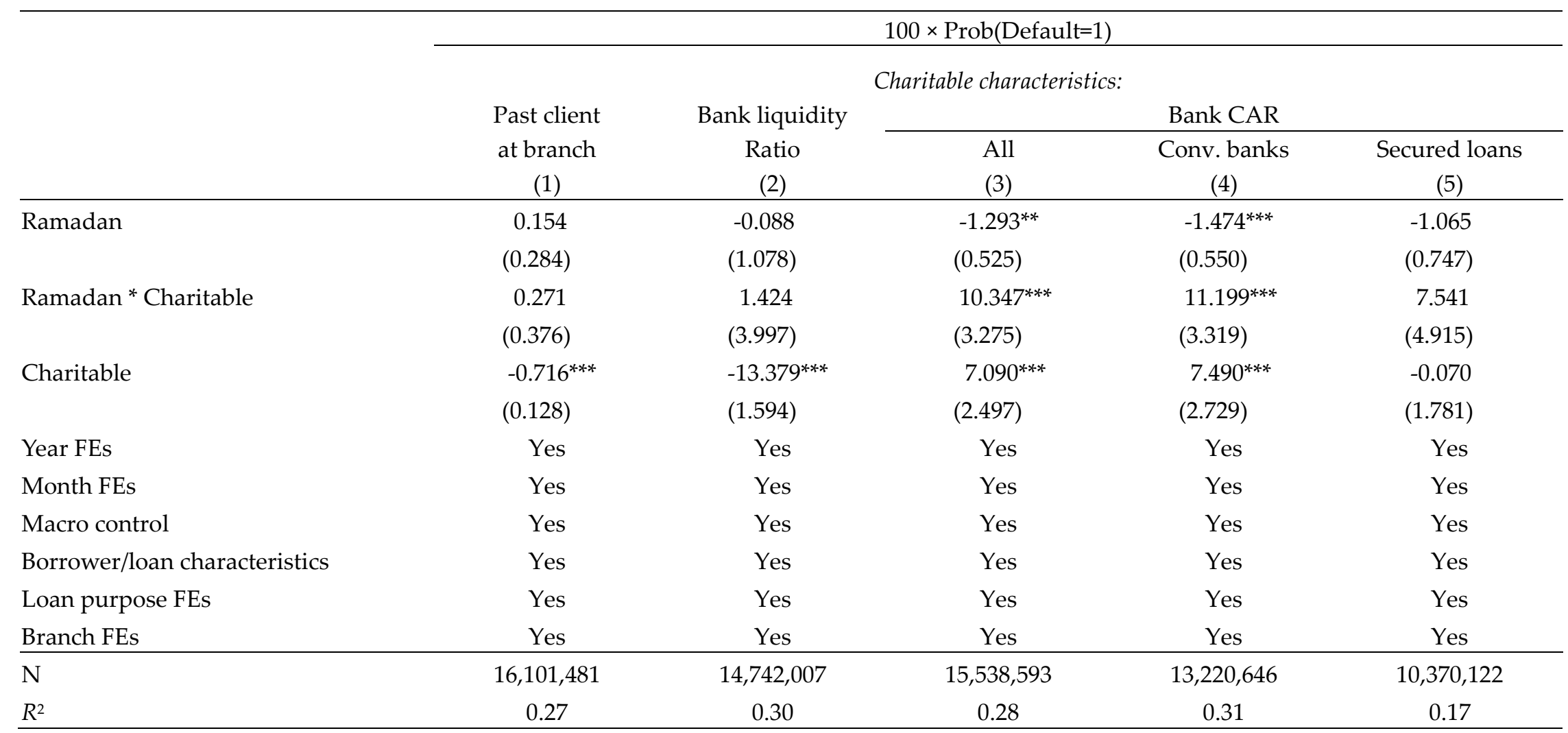


Table XI. Alternative Mechanisms

This table presents estimates from regressions exploring alternative mechanisms as drivers of small business loan defaults during Ramadan in the period 2003-2013. Column (1) uses the natural logarithm of the number of unique borrowers at the branch level to explore changes in workload mix among loan officers during Ramadan as a driver. Column (2) uses an indicator for small city to explore increased social mixing during Ramadan as a driver. Column (3) uses an indicator for a borrower's first loan in the data set to explore "entrepreneur fatigue" during Ramadan as a driver. Column (4) uses the borrower's internal risk rating as a measure of loan risk. Column (5) uses the collateral-to-loan ratio as an inverse measure of loan risk. The regressions include the same set of control variables in Column (3) of Table II. Standard errors that are heteroskedasticity-consistent and clustered at the month-year level are reported in parentheses beneath coefficient estimates. ${ }^{* *},{ }^{* *}$, or $^{*}$ indicates that the coefficient estimate is significant at the $1 \%, 5 \%$, or $10 \%$ level, respectively.

\section{$100 \times \operatorname{Prob}($ Default=1)}

\begin{tabular}{|c|c|c|c|c|c|}
\hline & \multicolumn{5}{|c|}{$100 \times \operatorname{Prob}($ Detault=1) } \\
\hline & \multicolumn{5}{|c|}{ Mechanism/Measure: } \\
\hline & $\begin{array}{l}\text { Branch } \\
\text { workload } \\
\text { mix }\end{array}$ & Social mixing & $\begin{array}{c}\text { Entrepreneur } \\
\text { fatigue } \\
\end{array}$ & \multicolumn{2}{|c|}{ Loan risk } \\
\hline & $\begin{array}{c}\text { Number of } \\
\text { borrowers } \\
(1)\end{array}$ & $\begin{array}{c}\text { Small city } \\
(2)\end{array}$ & $\begin{array}{c}\text { First-time } \\
\text { loan } \\
(3)\end{array}$ & $\begin{array}{c}\text { Internal risk } \\
\text { rating } \\
(4)\end{array}$ & $\begin{array}{c}\text { Collateral-to- } \\
\text { loan ratio } \\
(5)\end{array}$ \\
\hline \multirow[t]{2}{*}{ Ramadan } & 0.592 & $0.385^{* * *}$ & $0.364^{* *}$ & -0.491 & 0.460 \\
\hline & $(0.364)$ & $(0.115)$ & $(0.144)$ & $(1.630)$ & $(0.401)$ \\
\hline \multirow[t]{2}{*}{ Ramadan * Mechanism } & -0.028 & -0.107 & 0.176 & 0.398 & -0.123 \\
\hline & $(0.089)$ & $(0.094)$ & $(0.341)$ & $(0.658)$ & $(0.406)$ \\
\hline \multirow[t]{2}{*}{ Mechanism } & $-0.325^{* * *}$ & & $0.228^{* *}$ & $5.399^{* * *}$ & $-1.435^{* * *}$ \\
\hline & $(0.077)$ & & $(0.098)$ & $(0.242)$ & $(0.117)$ \\
\hline Year FEs & Yes & Yes & Yes & Yes & Yes \\
\hline Month FEs & Yes & Yes & Yes & Yes & Yes \\
\hline Macro control & Yes & Yes & Yes & Yes & Yes \\
\hline Borrower/loan characteristics & Yes & Yes & Yes & Yes & Yes \\
\hline Loan purpose FEs & Yes & Yes & Yes & Yes & Yes \\
\hline Branch FEs & Yes & Yes & Yes & Yes & Yes \\
\hline $\mathrm{N}$ & $16,101,481$ & $15,417,960$ & $15,379,688$ & $5,078,291$ & $16,101,481$ \\
\hline$R^{2}$ & 0.14 & 0.28 & 0.28 & 0.42 & 0.27 \\
\hline
\end{tabular}




\section{Table XII. Robustness}

This table presents our robustness checks on the relationship between Ramadan and the likelihood of default for small business loans. The regressions include the same set of control variables in Column (3) of Table II. Column (1) uses an indicator variable for loans originated during the 30 calendar days preceding Eid al-Adha (an Islamic holiday that starts 2 months and 10 days after Ramadan). Column (2) uses indicator variables for loans originated in the first, middle, and last 10 days of Ramadan. In years in which Ramadan has 29 days, the indicator variable for the middle of Ramadan is for 9 days. Column (3) restricts the sample to loans smaller than 100,000 TL (in 2008 prices) - the average default rate in this sample is 2.74 percent. Column (4) excludes loans originated by bank branches in Istanbul. Column (5) excludes loans originated in 2007 and 2008. Standard errors that are heteroskedasticity-consistent and clustered at the month-year level are reported in parentheses beneath coefficient estimates. ${ }^{* * *}{ }^{* *}$, or * indicates that the coefficient estimate is significant at the $1 \%, 5 \%$, or $10 \%$ level, respectively.

\begin{tabular}{|c|c|c|c|c|c|}
\hline & \multicolumn{5}{|c|}{$100 \times \operatorname{Prob}($ Default $=1)$} \\
\hline & $\begin{array}{c}\text { All loans } \\
\text { (1) }\end{array}$ & $\begin{array}{c}\text { All loans } \\
\text { (2) }\end{array}$ & $\begin{array}{c}\text { Size }<100 \mathrm{~K} \\
\text { (3) }\end{array}$ & $\begin{array}{c}\text { Exc. IST } \\
(4)\end{array}$ & $\begin{array}{c}\text { Exc. crisis } \\
\text { (5) }\end{array}$ \\
\hline 30 days preceding Eid al-Adha & $\begin{array}{l}-0.111 \\
(0.241)\end{array}$ & & & & \\
\hline First 10 days of Ramadan & & $\begin{array}{l}0.275^{* *} \\
(0.134)\end{array}$ & & & \\
\hline Middle 10 days of Ramadan & & $\begin{array}{c}0.431^{* * *} \\
(0.130)\end{array}$ & & & \\
\hline Last 10 days of Ramadan & & $\begin{array}{l}0.377^{* *} \\
(0.157)\end{array}$ & & & \\
\hline Ramadan & & & $\begin{array}{c}0.416^{* * *} \\
(0.135)\end{array}$ & $\begin{array}{c}0.366^{* * *} \\
(0.116)\end{array}$ & $\begin{array}{c}0.288^{* * *} \\
(0.107)\end{array}$ \\
\hline Year FEs & Yes & Yes & Yes & Yes & Yes \\
\hline Month FEs & Yes & Yes & Yes & Yes & Yes \\
\hline Macro control & Yes & Yes & Yes & Yes & Yes \\
\hline Borrower/loan characteristics & Yes & Yes & Yes & Yes & Yes \\
\hline Loan purpose FEs & Yes & Yes & Yes & Yes & Yes \\
\hline Branch FEs & Yes & Yes & Yes & Yes & Yes \\
\hline $\mathrm{N}$ & $16,101,481$ & $16,101,481$ & $12,857,494$ & $11,309,954$ & $13,393,879$ \\
\hline$R^{2}$ & 0.27 & 0.27 & 0.30 & 0.30 & 0.27 \\
\hline
\end{tabular}


Table IA.I: Robustness of the Main Results to Different Choices of Standard Error Clustering

We cluster regression standard errors in several different ways to check the robustness of the statistically significant Ramadan effect documented in Table II. We report standard errors in parentheses beneath coefficient estimates. ${ }^{* * *}, * *$, or ${ }^{*}$ indicates that the coefficient estimate is significant at the $1 \%, 5 \%$, or $10 \%$ level, respectively.

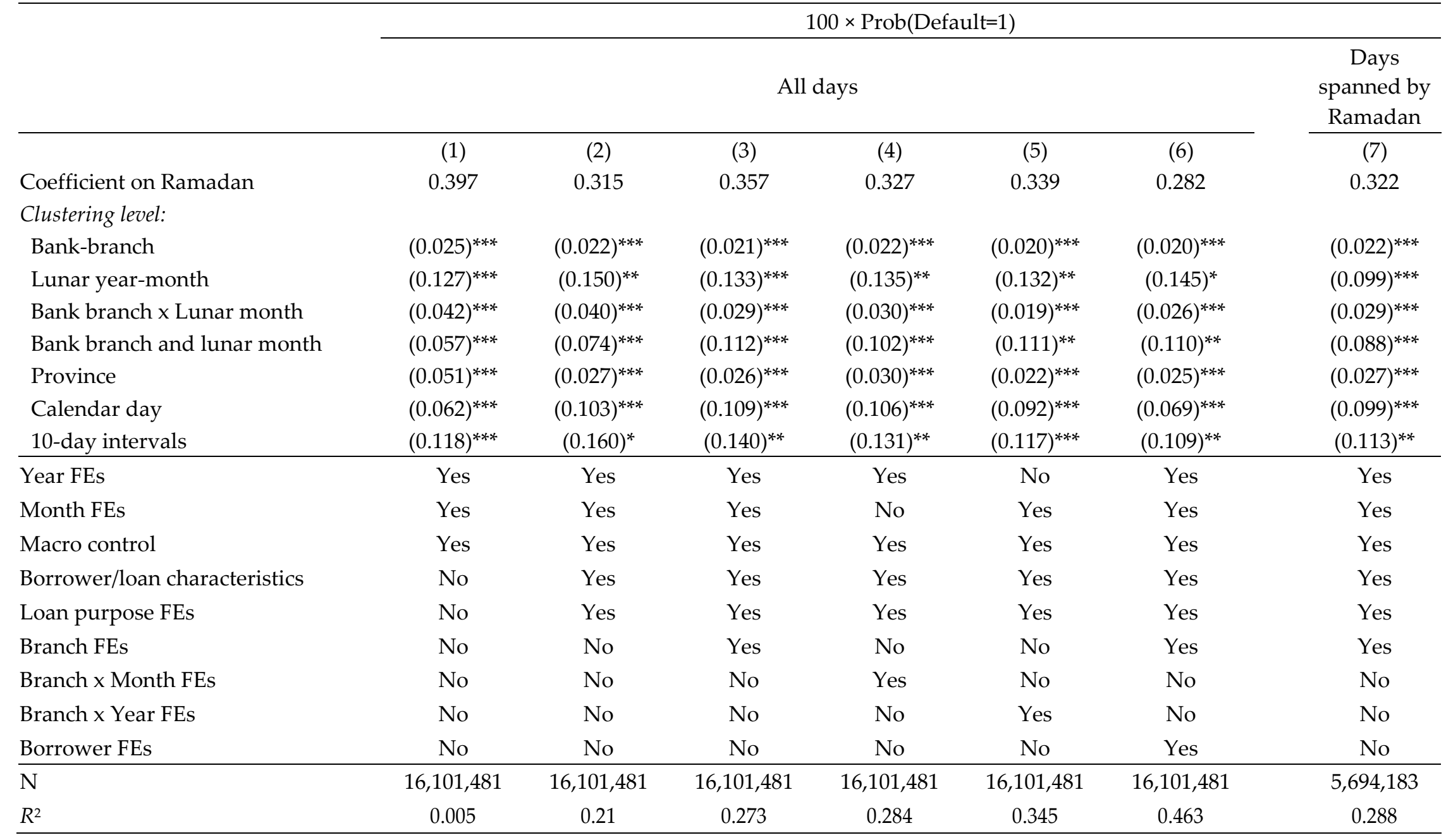




\section{Table IA.II: The Effect of Ramadan by Loan Security}

We estimate three separate regressions to examine how the effect of Ramadan on default rates of small business loans varies with loan security. In Column (1), the estimation sample consists of unsecured loans. In Column (2), we focus on "Undersecured" loans where the amount of the collateral is positive but less than the loan principal amount. In Column (3), the sample includes secured loans where the collateral amount is greater than or equal to loan amount. Standard errors that are heteroskedasticity-consistent and clustered at the month-year level are reported in parentheses beneath coefficient estimates. ${ }^{* * *},{ }^{* *}$, or ${ }^{*}$ indicates that the coefficient estimate is significant at the $1 \%, 5 \%$, or $10 \%$ level, respectively.

\begin{tabular}{lccc}
\hline & \multicolumn{3}{c}{$100 \times$ Prob(Default 1$)$} \\
\cline { 2 - 4 } & Unsecured & Undersecured & Secured \\
\cline { 2 - 4 } Ramadan & $(1)$ & $(2)$ & $(3)$ \\
\cline { 2 - 4 } Year FEs & $1.028^{* * *}$ & $0.238^{* *}$ & $0.119^{* *}$ \\
Month FEs & $(0.320)$ & $(0.116)$ & $(0.054)$ \\
Macro control & Yes & Yes & Yes \\
Borrower/loan characteristics & Yes & Yes & Yes \\
Loan purpose FEs & Yes & Yes & Yes \\
Branch FEs & Yes & Yes & Yes \\
\hline $\mathrm{N}$ & Yes & Yes & Yes \\
$R^{2}$ & Yes & Yes & Yes \\
\hline
\end{tabular}




\section{Table IA.III: Hot/Cold and Summer/Non-Summer Sample Splits}

We estimate the impact of Ramadan on the likelihood of default separately for hot vs. cold as well as summer vs. non-summer Ramadans. We divide loans by each branch within a year into four quartiles based on the total number of small business loans originated by the branch on the loan date, and use the subsample of loans in the top (busiest) quartile of branch-days in our estimations. The sample is further restricted to calendar days that feature Ramadan fasting at least once during 2003-2013. Standard errors that are heteroskedasticity-consistent and clustered at the month-year level are reported in parentheses beneath coefficient estimates. ${ }^{* *},{ }^{* *}$, or $^{*}$ indicates that the coefficient estimate is significant at the $1 \%, 5 \%$, or $10 \%$ level, respectively.

\begin{tabular}{lcccc}
\hline & \multicolumn{4}{c}{$100 \times$ Prob(Default=1) } \\
\cline { 2 - 5 } & $(1)$ & $(2)$ & $(3)$ & $(4)$ \\
& Hot & Cold & Summer & Non-Summer \\
\hline Ramadan & $0.611^{* * *}$ & 0.303 & $0.465^{* * *}$ & -0.040 \\
Year FEs & $(0.169)$ & $(0.229)$ & $(0.149)$ & $(0.301)$ \\
Month FEs & Yes & Yes & Yes & Yes \\
Macro control & Yes & Yes & Yes & Yes \\
Borrower/loan characteristics & Yes & Yes & Yes & Yes \\
Loan purpose FEs & Yes & Yes & Yes & Yes \\
Branch FEs & Yes & Yes & Yes & Yes \\
\hline $\mathrm{N}$ & Yes & Yes & Yes & Yes \\
$R^{2}$ & 261,458 & 511,913 & 264,183 & 663,108 \\
\hline
\end{tabular}


Table IA.IV: Robustness of the Main Results to the Exclusion of Borrower and Loan Characteristics

This table presents the main results of the paper (reported in Table II) without the inclusion of borrower and loan characteristics as controls. Standard errors that are heteroskedasticity-consistent and clustered at the month-year level are reported in parentheses beneath coefficient estimates. ${ }^{* * *}{ }^{* *}$, or ${ }^{*}$ indicates that the coefficient estimate is significant at the $1 \%, 5 \%$, or $10 \%$ level, respectively.

\begin{tabular}{|c|c|c|c|c|c|c|c|}
\hline & \multicolumn{7}{|c|}{$100 \times \operatorname{Prob}($ Default=1) } \\
\hline & \multicolumn{6}{|c|}{ Full sample } & \multirow{2}{*}{$\begin{array}{c}\text { Days spanned by } \\
\text { Ramadan } \\
(7) \\
\end{array}$} \\
\hline & $(1)$ & $(2)$ & $(3)$ & $(4)$ & $(5)$ & (6) & \\
\hline Ramadan & $\begin{array}{c}0.397^{* * *} \\
(0.116)\end{array}$ & $\begin{array}{l}0.302^{* *} \\
(0.125)\end{array}$ & $\begin{array}{c}0.331^{* * *} \\
(0.123)\end{array}$ & $\begin{array}{l}0.299^{* *} \\
(0.125)\end{array}$ & $\begin{array}{l}0.298^{* *} \\
(0.134)\end{array}$ & $\begin{array}{c}0.243^{*} \\
(0.123)\end{array}$ & $\begin{array}{c}0.294^{* * *} \\
(0.081)\end{array}$ \\
\hline Year FEs & Yes & Yes & Yes & Yes & No & Yes & Yes \\
\hline Month FEs & Yes & Yes & Yes & No & Yes & Yes & Yes \\
\hline Macro control & Yes & Yes & Yes & Yes & Yes & Yes & Yes \\
\hline Loan purpose FEs & No & Yes & Yes & Yes & Yes & Yes & Yes \\
\hline Branch FEs & No & No & Yes & No & No & Yes & Yes \\
\hline Branch $x$ Month FEs & No & No & No & Yes & No & No & No \\
\hline Branch $x$ Year FEs & No & No & No & No & Yes & No & No \\
\hline Borrower FEs & No & No & No & No & No & Yes & No \\
\hline $\mathrm{N}$ & $16,101,481$ & $16,101,481$ & $16,101,481$ & $16,101,481$ & $16,101,481$ & $16,101,481$ & $5,694,183$ \\
\hline$R^{2}$ & 0.01 & 0.05 & 0.08 & 0.09 & 0.13 & 0.37 & 0.09 \\
\hline
\end{tabular}

